\title{
Glacier Mass-Balance Variation in China during the Past Half Century
}

\author{
Yousif Elnour Yagoub ${ }^{12 *}$, Zhongqin Li' ${ }^{1}$, Ahmed A. H. Siddig², \\ Omer Said Musa ${ }^{2}$, Muhammad Naveed Anjum ${ }^{3}$
}

\author{
${ }^{1}$ State Key Laboratory of Cryospheric Sciences/Tian Shan Glaciological Station, Northwest Institute of Eco-Environment and \\ Resources, CAS, Lanzhou, China \\ ${ }^{2}$ Faculty of Forestry, Department of Forest Protection and Conservation, University of Khartoum, Shambat, Sudan \\ ${ }^{3}$ Division of Hydrology Water-Land Resources, Northwest Institute of Eco-Environment and Resources, CAS, Lanzhou, China \\ Email: ^yousif@lzb.ac.cn, *yousifelnouryagoub@yahoo.com
}

How to cite this paper: Yagoub, Y.E., Li, Z.Q., Siddig, A.A.H., Musa, O.S. and Anjum, M.N. (2018) Glacier Mass-Balance Variation in China during the Past Half Century. Journal of Geoscience and Environment Protection, 6, 37-58. https://doi.org/10.4236/gep.2018.65004

Received: March 20, 2018

Accepted: May 20, 2018

Published: May 23, 2018

\begin{abstract}
The aim of this study is to investigate the impact of temperature trend on glacier-mass balance, snow density, snowmelt, snow depth and runoff by using observations of nine glacier stations that covered most of the China over the period of 1979-2013. Trend analysis showed an increasing trend of temperature on all of the selected stations. On an average, temperature $\left({ }^{\circ} \mathrm{C}\right)$ was increasing at the rate of $0.46 / 10 \mathrm{a}$. The increasing trend of temperature showed a negative relationship with annual glacier-mass balance on most of the stations and caused a decrease in annual balance. Results of Pearson's correlation analysis showed a highly significant negative correlation between temperature and snow density (correlation coefficient $(\mathrm{CC}=-0.661$ at 0.01 significance level). There was a significant positive correlation between temperature and snowmelt ( $\mathrm{CC}=0.532$ at 0.01 significance level). There was a significant negative correlation between temperature and snow depth (correlation coefficient ( $C C=-0.342$ at 0.05 significance level). Moreover, there was a significant positive correlation between temperature and runoff $(C C=0.586$ at 0.01 significance level). Increasing trend of temperature caused an increasing trend of annual snowmelt and runoff anomaly\% at the rate of 24.82/10a and 9.87/10a, respectively. On the other hand, a declining trend in annual snow density and snow depth anomaly\% was found at a rate of $-5.32 / 10 \mathrm{a}$ and $-1.93 / 10 \mathrm{a}$, respectively. We concluded that the snow density, snowmelt and runoff are significantly sensitive to temperature in China. This contribution has provided information for further understanding of glacier variation and its influencing factors.
\end{abstract}

\section{Keywords}

Glacier Mass-Balance, Snow Density, Snowmelt, Snow Depth, Runoff, Climate 
Variation

\section{Introduction}

Global climate models predict that the Arctic will experience greater than global average temperature and precipitation increases in response to the build-up of greenhouse gases [1]. The largest glacierized region outside the Arctic and Antarctic is Himalayan. Glacier changes in this region are spatially heterogeneous and not well known. Himalayan glaciers are a focus of public and scientific debate. Prevailing uncertainties are of major concerns because some projections of their future have serious implications for water resources. Most Himalayan glaciers are losing mass at rates similar to glaciers elsewhere [2]. Global climate change is driving the behavior of mountain glaciers worldwide [3]. Based on the observed global air and ocean temperatures, it can be said that the rate of temperature increase is higher at higher altitudes [4].The seasonal melt maxima happen around 15 - 20 July through the whole 21 st century and coincide with the rising temperature. In the second half of the century, the temperature and, therefore, the melts are projected to increase more after their seasonal maximum than at the beginning of summer. The melt asymmetry is also partly explained by changing snowfall that is projected to increase before June but to significantly decrease in late summer [5]. Climate warming has impacted in most mountain glaciers, including glaciers in the Tianshan Mountains, which are in a state of rapid terminus retreat [6] [7]. Increasing temperatures have resulted in the loss of more than half of the glaciers in Asia since 1900 [8]. In addition, any decrease in glacier melt runoff often also leads to economic losses and associated negative social consequences [9]. Adverse impacts associated with a decrease of snow and ice and the related changes in melt runoff can affect societies seriously [10]. The climate with the physical properties of ice determines the extent and behavior of glaciers, a statement that underpins the rationale for the examination of former and contemporary glacier behavior, leading to an examination of past and present glacier behavior within a climatic context [11]. The problem statement and justifications of this research are that the glaciers retreat will eventually lead to loss of frozen water resource, glacier areas have a wide range of practical applications in water resource, they support the sustainable development of the arid and semi-arid environment systems in the west China. Glacier runoff is the main contributor to water supplies for agriculture in the western China. In these regions, glacier meltwater has been described to play a crucial role for irrigation during the hot and dry seasons [12]. Glaciers in the west of China have been retreating over the past 56 years. Glacier melting causes negative mass balance with strong impacts on the quantity and seasonal distribution of runoff in the western China. Monitoring the long-term behavior of surge-type glaciers and detailed study of individual surges is essential for improving our knowledge of 
the physical mechanisms behind surging [13].Water resources provided by alpine glaciers are an important pillar for people in the arid regions of the western China [14].

The hypotheses of this research are that the climate change is the main factor causing glacier variations. The summer temperature and precipitation were basic factors to determine the ablation and accumulation of glaciers. The glaciers were been affected by the increasing temperature in the long timescale. On the other hand, precipitation is only obvious for short-term and small-scale of glaciers. According to [15] much remains unknown about the system's history before the mid-nineteenth century and the hydrological characteristics and processes of both glaciers.

The main objectives of this study, to explore and analyze the spatial and temporal patterns of climate variability impacts such as temperature on glacier annual balance, snow density, snowmelt, snow depth and snowmelt runoff. To this end, analyses of correlation of climatic factors and their correlations with glacier mass balance; analyses of glacier mass balance variations; an estimation of temperature and glacier mass correlations; to identify knowledge gaps that should be addressed in future research in addition to those indicated in previous publications.

\section{Material and Methods}

\subsection{Data Collection}

Monthly temperature and precipitation records of climatic stations are derived from the China Meteorological Data Service Center http://data.cma.gov.cn. The glacier annual balance was obtained from world glacier monitoring service WGMS http://wgms.ch/data_databaseversions/. In addition, the data of snow density, snowmelt, snow depth and runoff were obtained from http://apps.ecmwf.int/datasets/data/interim-mdfa/levtype\%3Dsfc European Centre for Medium-Range Weather Forecasts (ECMWF) for the period of 1979-2013.

\subsection{Anomaly Percent}

In this paper, the formulation of percent anomaly (\%) reflects the direct result of simple principle which reflects the period of the snow properties such as snow density, snowmelt, snow depth and runoff. The count formula is given below:

$$
\text { Anomaly } \%=\frac{x-\bar{x}}{\bar{x}} \times 100
$$

where, $x$ is the snow property of specific period, $\bar{x}$ is average of snow property of the specific period. The advantage of anomaly percent is that it has a simple and clear meaning.

\subsection{Study Area}

For the present analysis, we have selected the western part of China, because 
most of the glaciers in China are situated in western parts of the country. In this study, glaciers located in the west of China are divided into nine stations according to their locations (their WGMS IDs are 849, 853, 856, 1510, 3694, 3955, 3978, 3987 and 3991 (Table 1 and Figure 1). This study area has a complex and diverse climate types, variegations of temperature and precipitation, dry climate, uneven distribution of water resources and serious water shortages in the northwest part of the China, harsh natural conditions and high frequency of drought.

\section{Results}

\subsection{Analysis of Climate Factors}

In fact, the understanding of the relationship between climate factors with glacier mass-balance in past decades is very important for prediction of future trends. A significantly increasing trend of temperature $\left({ }^{\circ} \mathrm{C}\right)$ covered all the nine stations (Figure 2). The warming rate of 1979-2013 mainly was 0.32/10a, 0.47/10a, 0.49/10a, 0.58/10a, 0.46/10a, 0.57/10a, 0.47/10a, 0.26/10a and 0.56/10a, respectively, in the HAILUOGOU, URUMQI GLACIER NO. 1, QIYI, XIAO DONGKZMADI, KANGWURE, MEIKUANG, GURENHEKOU, PARLUNG NO. 94 and NAIMONA NYI. The surface temperatures on mountain glaciers have direct reflections of heat budget on the glacier surface, which controls the degree of ablation. An understanding of surface temperatures is therefore crucial in simulating the evolution of mountain glaciers and in understanding a glacier's response to climate change [16]. Recently, [17] reported that the average temperature has increased at the rate of $0.3^{\circ} \mathrm{C} / 10 \mathrm{a}(1961-2010)$ on the 533 selected meteorological stations around the China. Global mean temperature has increased by $0.85^{\circ} \mathrm{C}$, over the period of 1880 to 2012 and this increase in temperature is likely due to anthropogenic activities that have increased the concentrations of greenhouse gases to unprecedented levels [18]. As shown in Figure 3, a great discrepancy existed in precipitation with increase or decrease rate. There is

Table 1. The study area with name, WGMS: ID, general name, special location, latitude and longitude.

\begin{tabular}{ccccc}
\hline Name & WGMS: ID & GEN LOCATION & Lat & Long \\
\hline Hailuogou & 849 & HENGDUAN SHAN & 29.58 & 101.93 \\
Urumqi Glacier No. 1 & 853 & TIAN SHAN & 43.00 & 87.00 \\
Qiyi & 856 & QILIAN SHAN & 39.24 & 97.76 \\
Xiao Dongkzmadi & 1510 & TIBETAN PLATEAU & 33.17 & 92.13 \\
Kangwure & 3694 & HIMALAYA & 28.45 & 85.75 \\
Meikuang & 3955 & KUNLUN MT. E & 35.67 & 94.18 \\
Gurenhekou & 3978 & TIBETAN PLATEAU & 30.18 & 90.47 \\
Parlung N0. 94 & 3987 & SOUTHEAST TIBETAN PLATEAU & 29.39 & 96.98 \\
Naimona Nyi & 3991 & HIMALAYA W & 30.45 & 81.33 \\
\hline
\end{tabular}



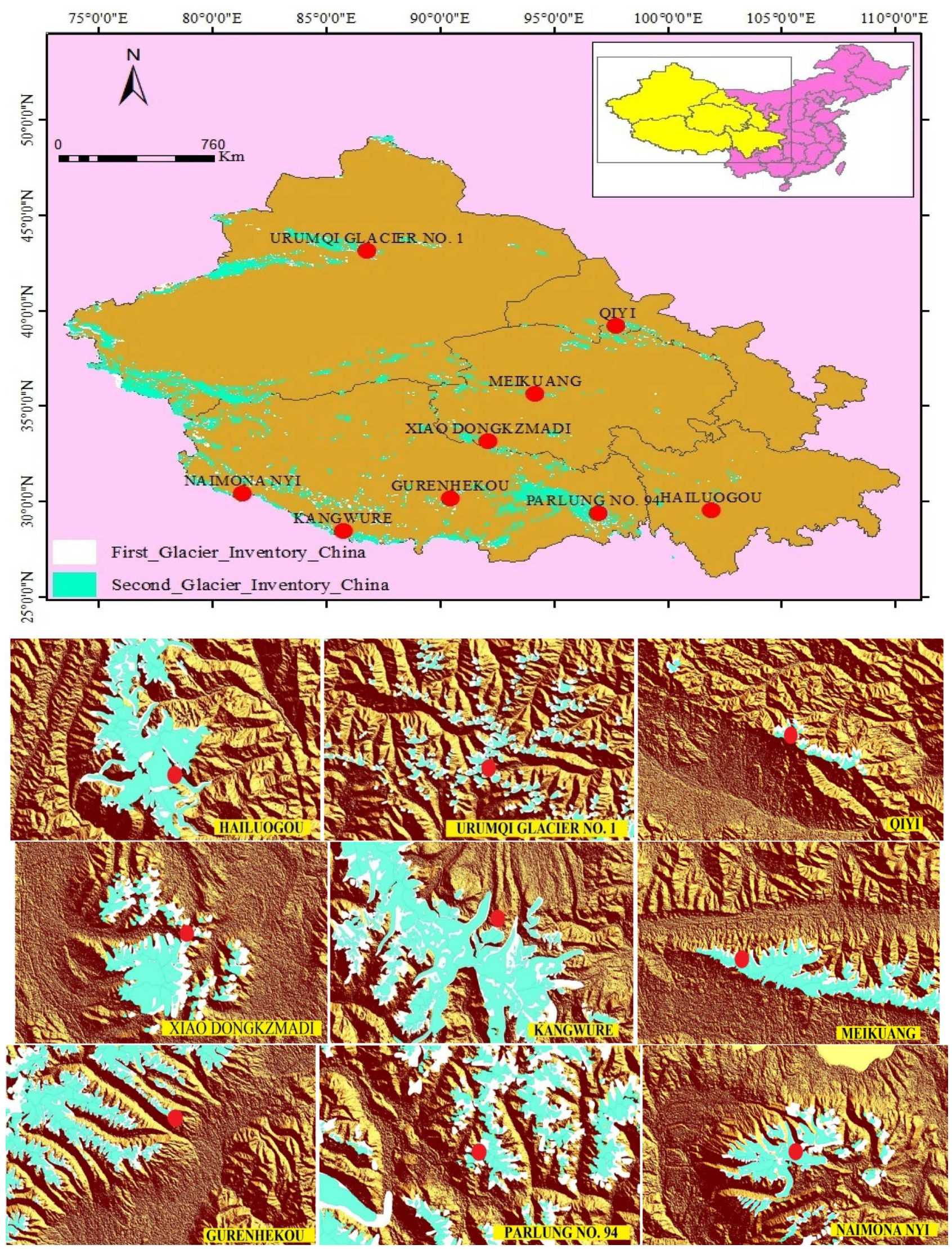

Figure 1. Location of the study area including nine glacier stations with a distribution of first and second glacier inventory. 

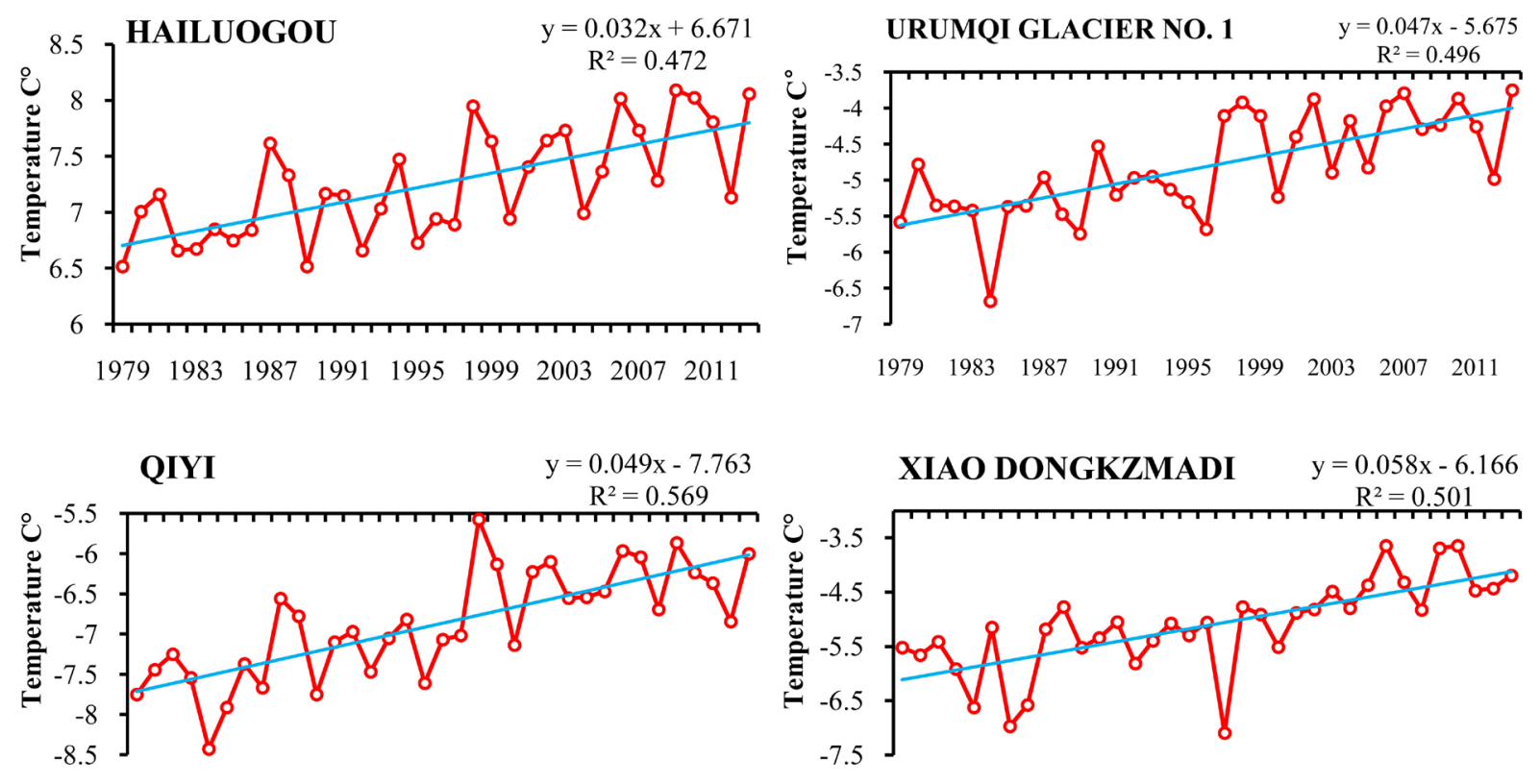

197919831987199119951999200320072011

197919831987199119951999200320072011
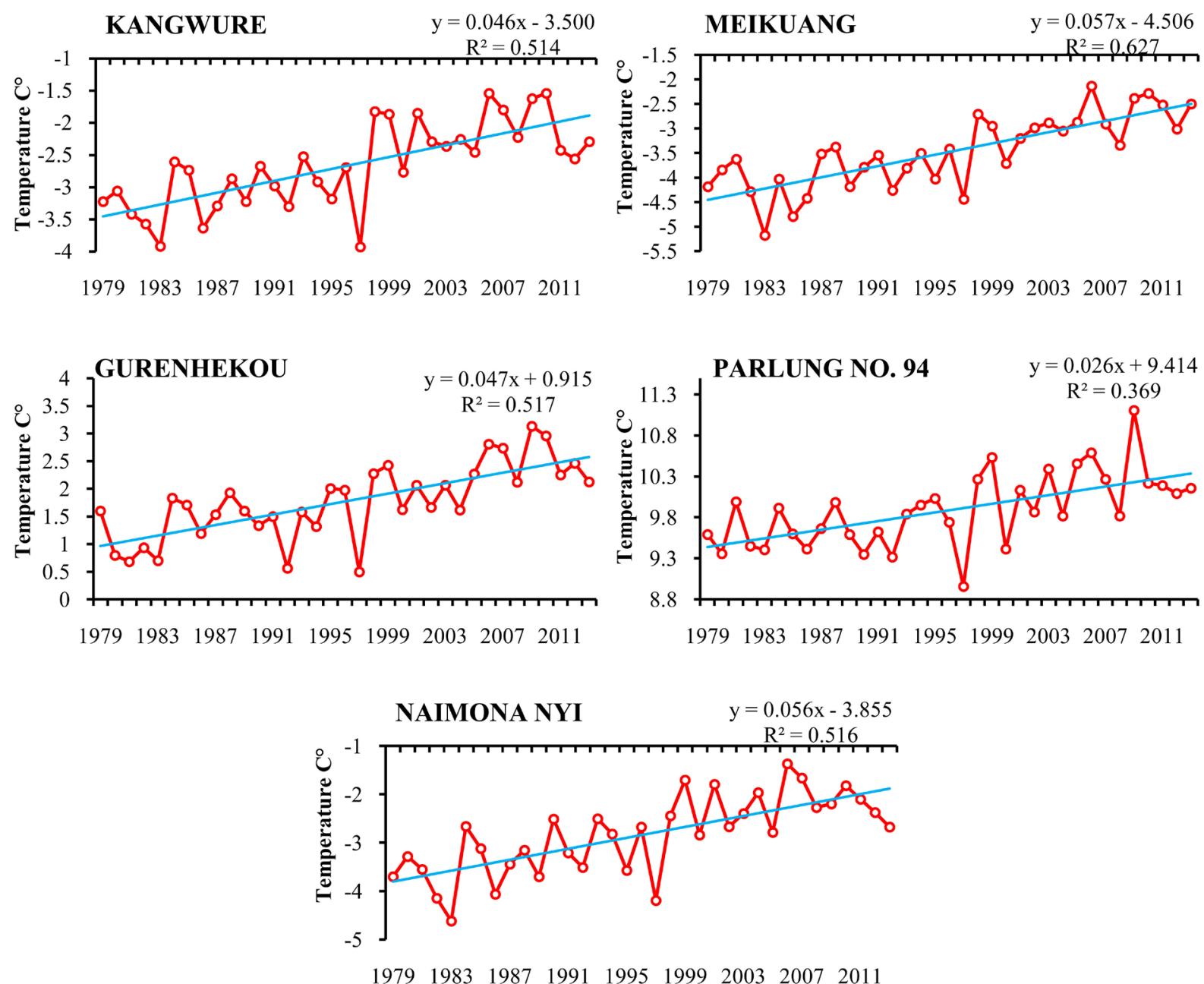

Figure 2. Changes in annual temperature $\left({ }^{\circ} \mathrm{C}\right)$ of the nine meteorological stations during 1979-2013. 


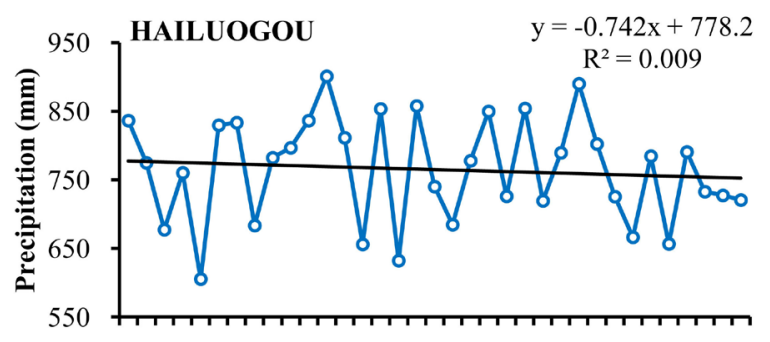

197919831987199119951999200320072011

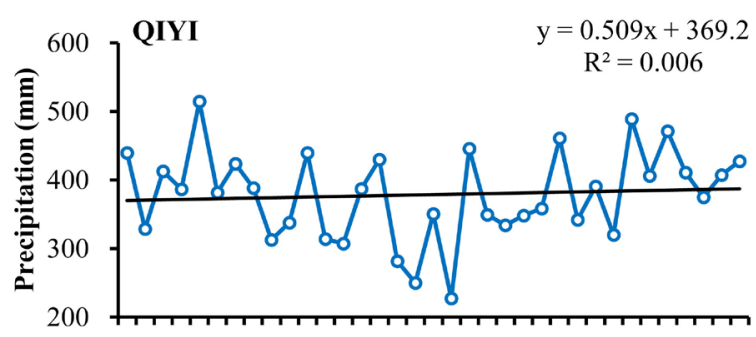

197919831987199119951999200320072011

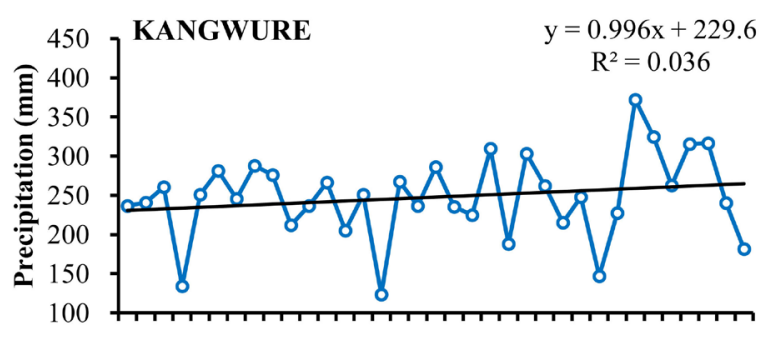

197919831987199119951999200320072011
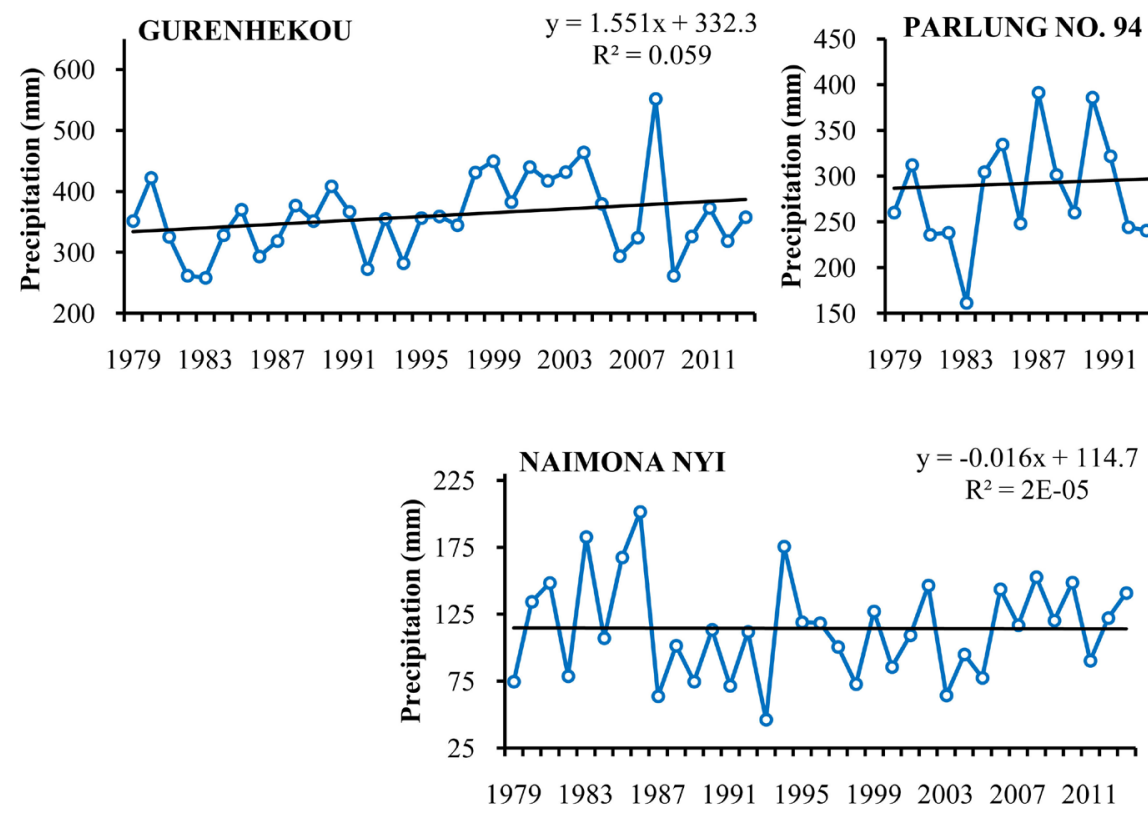

URUMQI GLACIER NO. $1 \quad \mathrm{y}=3.347 \mathrm{x}+411.4$

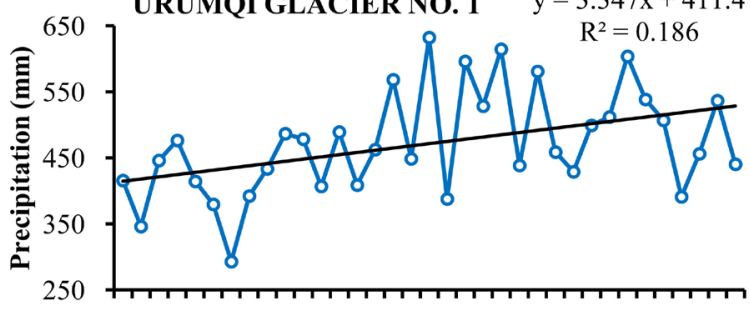

197919831987199119951999200320072011

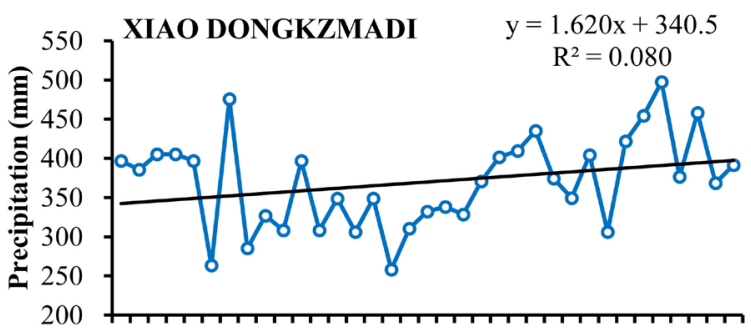

197919831987199119951999200320072011
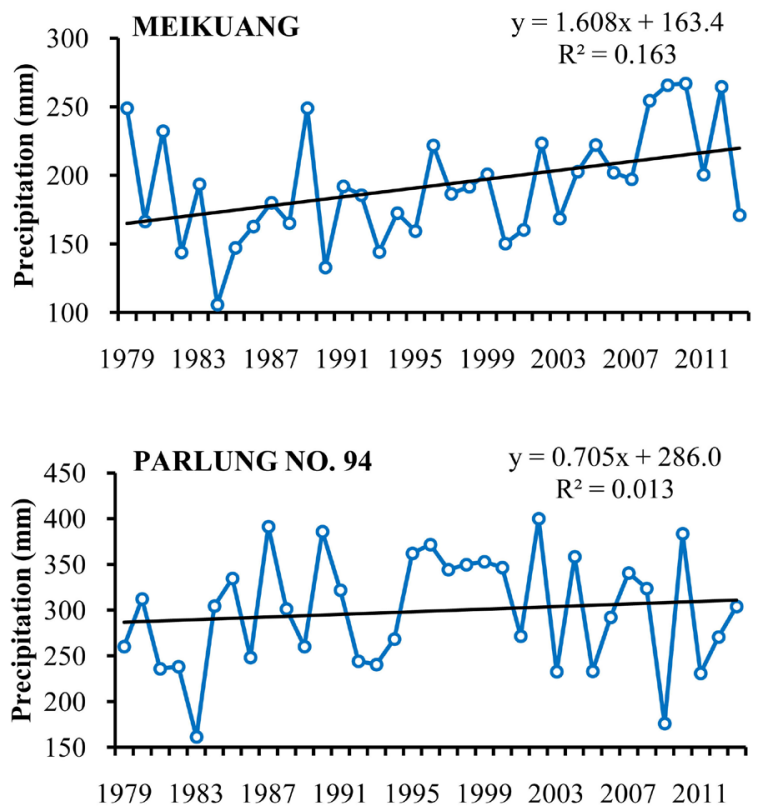

197919831987199119951999200320072011

$y=-0.016 \mathrm{x}+114.7$

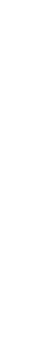

Figure 3. Changes in annual precipitation $(\mathrm{mm})$ of the nine meteorological stations during 1979-2013. 
a significant increase in URUMQI GLACIER NO. 1, QIYI, XIAO DONGKZMADI, KANGWURE, MEIKUANG, GURENHEKOU and PARLUNG NO. 94. A declining trend in precipitation was found only in the HAILUOGOU and NAIMONA NYI. [19] reported an increasing trend in winter and spring temperature and decreasing trends of precipitation, a significant negative trend in snow cover area during these seasons identified in Himalaya. The observed increase in summer temperatures and the related glacier down wasting has led to a noticeable decrease of frozen water resources in Central Asia, with possible future impacts on the economy of all downstream countries in the region [20]. The annual and seasonal climatic trends resulted in shrinkage of glaciers in the Chinese Tianshan over the last century, especially in the recent decades, thus, this causing a serious impact on the hydrological regime of this area (e.g., Li et al., 2010; [6]).

\subsection{The Glacier Annual Balance}

As shown in Figure 4, a high decreasing rate of annual glacier-mass balance (m. w.e.) occurred in HAILUOGOU, URUMQI GLACIER NO. 1, QIYI, XIAO DONGKZMADI, KANGWURE, MEIKUANG, GURENHEKOU, PARLUNG NO. 94 and NAIMONA NYI, with the rates of $-1.186 / 10 \mathrm{a},-0.18 / 10 \mathrm{a},-0.21 / 10 \mathrm{a}$, $-0.31 / 10 \mathrm{a},-0.14 / 10 \mathrm{a},-0.25 / 10 \mathrm{a},-1.41 / 10 \mathrm{a},-0.35 / 10 \mathrm{a}$ and $-0.03 / 10 \mathrm{a}$, respectively. There is a general trend of glacial retreat and mass defect worldwide during the past several decades [21] [22]. The glacier retreat since the Little Ice Age, i.e. during the period of $15^{\text {th }}-19^{\text {th }}$ centuries in the China [23]. Understanding the glacier mass balance is necessary to explain the rate of shrinkage and to infer the impact of climate change. The mean rate of glacial mass balance trend in China decreased by $-0.015 \mathrm{~m}$ w.e. (water equivalent) per year during the period 1959-2015. Which was lower than that for glaciers globally $-0.013 \mathrm{~m}$ w.e. per year). It indicated that the rate of glacial melting (mass loss) in the China was higher than that in glaciers worldwide [24]. In fact, glaciers in the Himalaya have experienced a decline since the end of the Little Ice Age [25], also at an increased declining rate during the past few decades [26]. There has been a great deal of attention given to understanding the increasing temperature and decreasing snow accumulation in the Himalayas due to observed and projected warming [27]. Rapid shrinkage and dramatic volume loss of the glaciers in the eastern Tianshan Mountains have resulted in water shortages in the surrounding arid regions of China [28]. The Kangwure Glacier has experienced a significant mass deficit since 1970 s, with $34.2 \%$ of area loss, $48.2 \%$ of ice volume loss and $7.5 \mathrm{~m}$ of average thickness decrease. The investigating in Kangwure Glacier during the recent few decades, found that the length, area, volume and average thickness of this glacier have decreased by $9 \%, 34.2 \%, 48.2 \%$ and $7.5 \mathrm{~m}$, respectively [29]. Glaciers in the Tibetan Plateau have been retreating during the past few decades resulting from global warming [30]. During 1970-2007, overall annual temperatures increased gradually in the north to south of the West Nyainqentanglha 

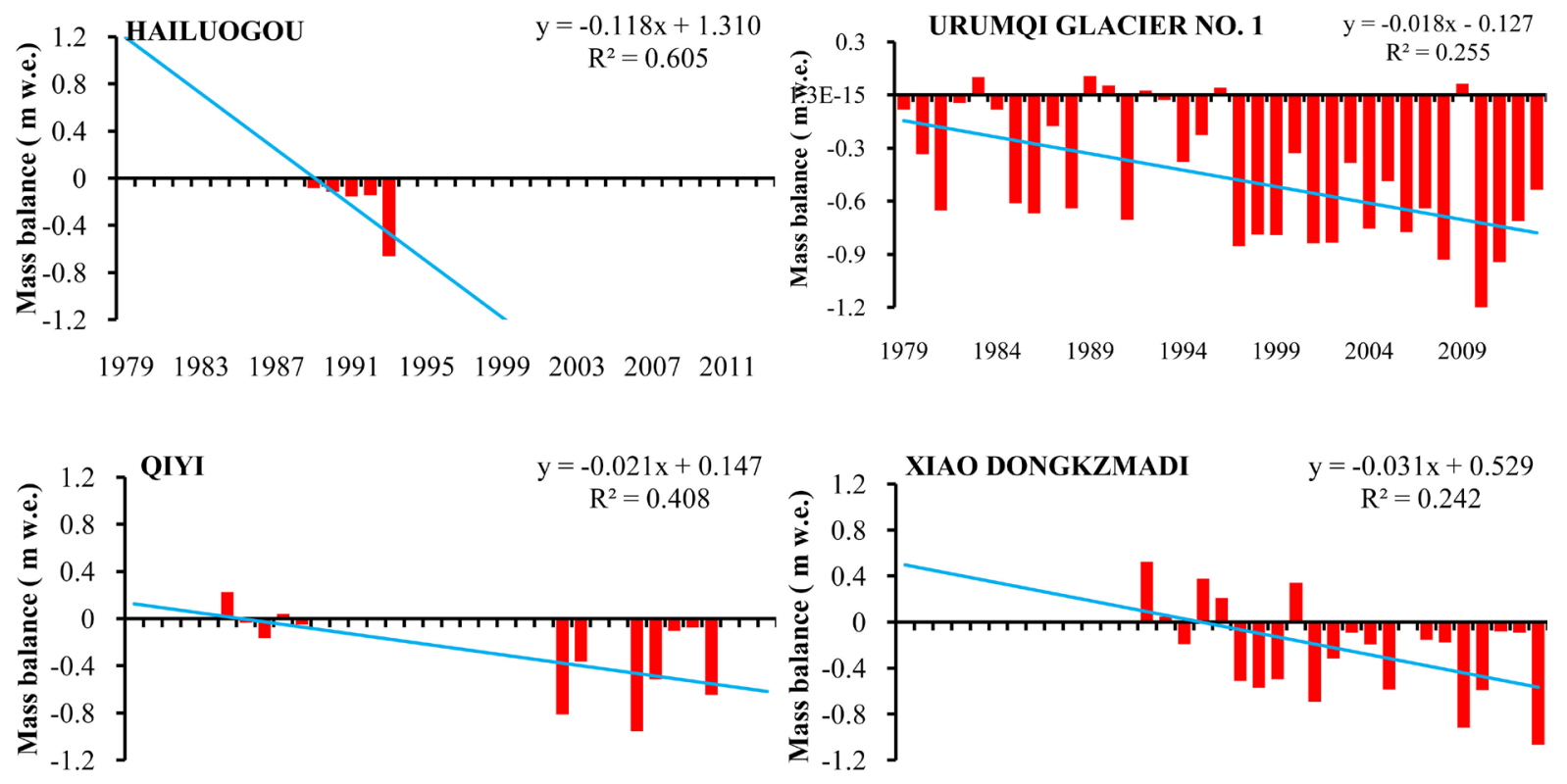

$\begin{array}{lllllllll}1979 & 1983 & 1987 & 1991 & 1995 & 1999 & 2003 & 2007 & 2011\end{array}$

$\begin{array}{lllllllll}1979 & 1983 & 1987 & 1991 & 1995 & 1999 & 2003 & 2007 & 2011\end{array}$
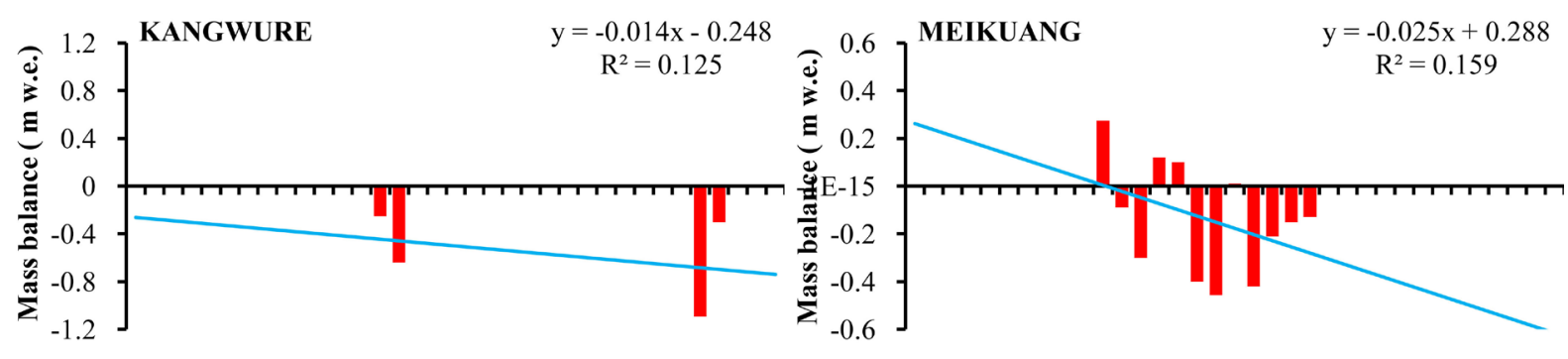

$\begin{array}{lllllllll}1979 & 1983 & 1987 & 1991 & 1995 & 1999 & 2003 & 2007 & 2011\end{array}$

197919831987199119951999200320072011

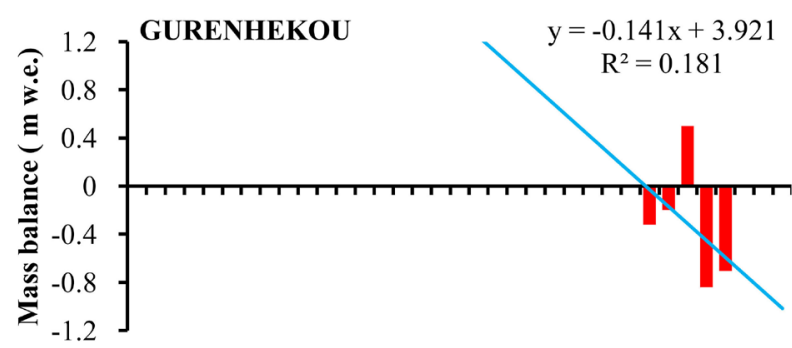

197919831987199119951999200320072011

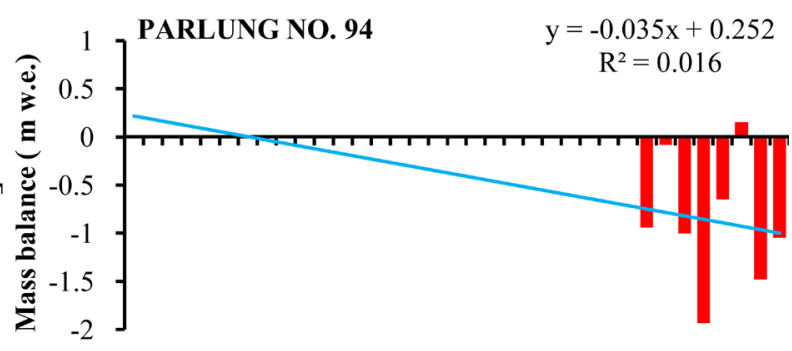

197919831987199119951999200320072011

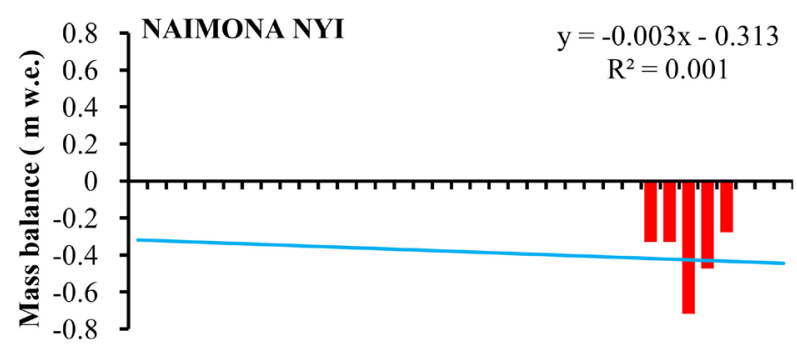

197919831987199119951999200320072011

Figure 4. The annual glacier-mass balance (m w.e.) of the nine stations during 1979-2013. 
Range, respectively, resulting in the areas of the two glaciers reduced over the last nearly four decades. The rate of temperature increase in the north is higher than that in the south [31]. Since the 1990s, the URUMQI GLACIER NO. 1 and XIAO DONGKZMADI stations showed a high significant decrease in annual mass balance.

\subsection{The Snow Density}

There are many discrepancies in annual snow density anomaly\% is shown in Figure 5. The decline rate of annual snow density anomaly\% was $-3.63 / 10 \mathrm{a}$, $-6.38 / 10 \mathrm{a},-7.11 / 10,-1.67 / 10 \mathrm{a},-5.65 / 10 \mathrm{a},-5.92 / 10 \mathrm{a},-3.94 / 10 \mathrm{a},-8.01 / 10 \mathrm{a}$ and 5.58/10a, respectively in HAILUOGOU, URUMQI GLACIER NO. 1, QIYI, XIAO DONGKZMADI, KANGWURE, MEIKUANG, GURENHEKOU, PARLUNG NO. 94 and NAIMONA NYI. The glacier in QIYI station has seriously shrinking over the past 37 (during 1972-2009) years. The glacier terminal retreated about $6 \%$, the area reduced about $13.1 \%$, the volume reduced about $35.3 \%$, and glacier shrinkage is mainly in the form of thinning. Glacier average thickness reduced from $36.8 \mathrm{~m}$ in 1972, to $27.4 \mathrm{~m}$ in 2009. Meteorological data around the study area shows that this region in recent decades has undergone differential warming which is the main reason for rapid glacier shrinkage [32]. The glacier sensitivity tests indicate that in the Payuwang Valley in western Nyaiqentanggulha Shan, the glaciers responded to centennial-scale shifts in climate. The tributary glaciers coalesce into the main valley and expand rapidly there [33].

\subsection{The Snowmelt}

As shown in Figure 6, a high increasing rate of annual snowmelt anomaly\% occurred in HAILUOGOU, URUMQI GLACIER NO. 1, QIYI, KANGWURE, GURENHEKOU, PARLUNG NO. 94 and NAIMONA NYI, with the rates of 67.43/10a, 3.91/10a, 4.4/10a, 73.07/10a, 28.98/10a, 57.48/10a and 16.2/10a, respectively. Since 1974, the Kangwure Glacier has retreated $303 \mathrm{~m}$. The area changed from $2.98 \mathrm{~km}^{2}$ to the present $1.96 \mathrm{~km}^{2}$, with a loss of $34.2 \%$ of the area. The ice volume reduced from $0.0998 \mathrm{~km}^{3}$ to $0.0517 \mathrm{~km}^{3}$, a decrease of $48.2 \%$ in the past 3 decades. The calculation also shows that the glacier average thickness was reduced by $7.5 \mathrm{~m}$. These give a direct impression about the detailed glacier change in the Kangwure Glacier [29]. Nyainqentanglha mountain glacier surface elevations were decreased by $8.39 \pm 0.45 \mathrm{~m}$ during 2003-2009. Over the same period, at least $1.01 \mathrm{~km}^{3}$ of glacial melt water flowed into the Nam Co Lake, assuming a glacial runoff coefficient of 0.6 . The mean glacier mass-balance value was $-0.4 \mathrm{~m}$ w.e. indicating that glacier melt water in the catchment contributes to lake level rise. The contribution rate of glacial melt water to the lake volume rise was $20.75 \%$ [34]. In Central Asia, the melt water from glaciers provides an estimated 20\% $40 \%$ of total runoff during summers, both as a seasonal contribution and from glacier imbalance, up to $70 \%-80 \%$ in extremely hot and dry periods [35]. 


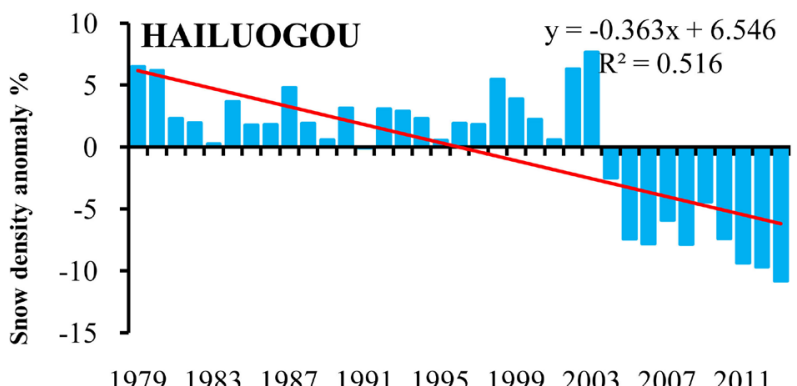

197919831987199119951999200320072011

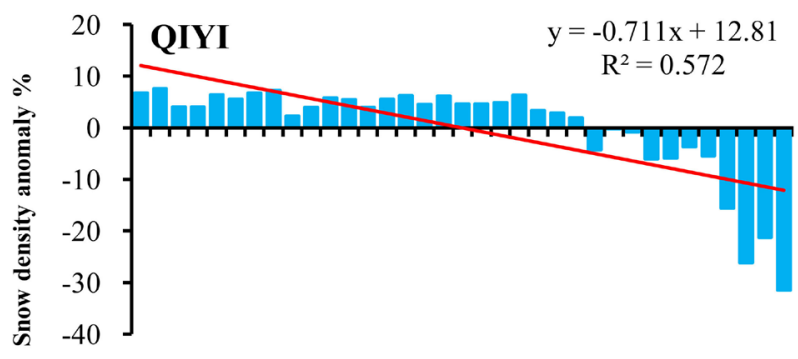

197919831987199119951999200320072011

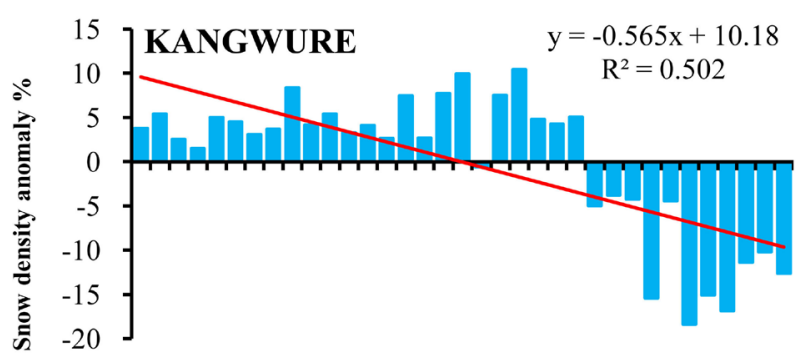

$\begin{array}{lllllllll}1979 & 1983 & 1987 & 1991 & 1995 & 1999 & 2003 & 2007 & 2011\end{array}$

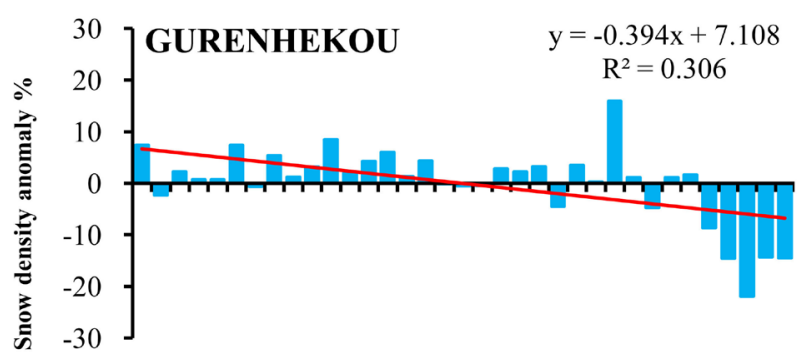

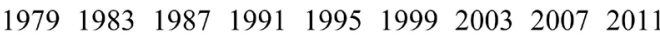
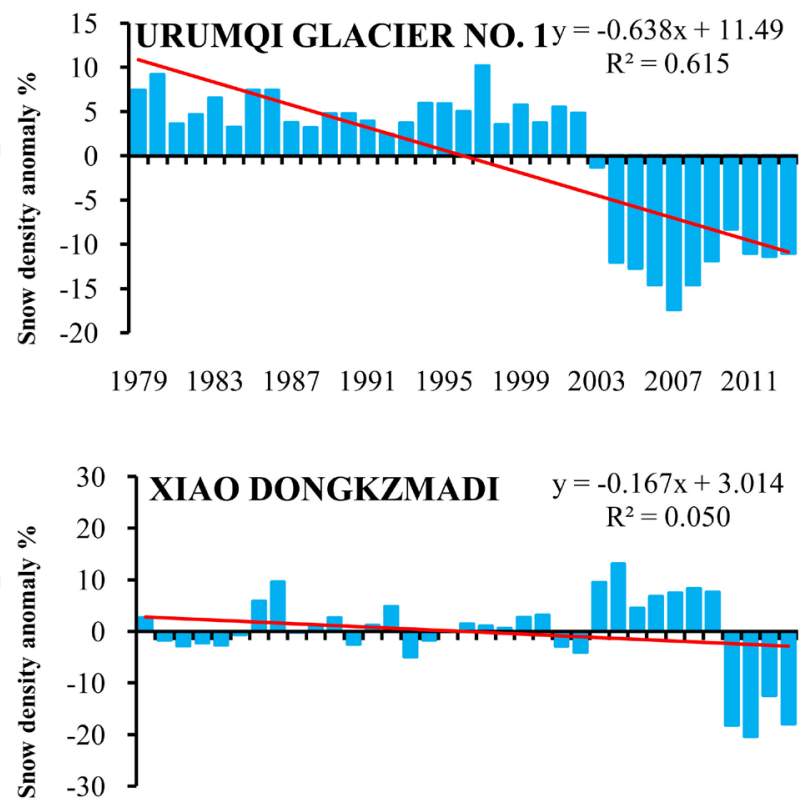

197919831987199119951999200320072011

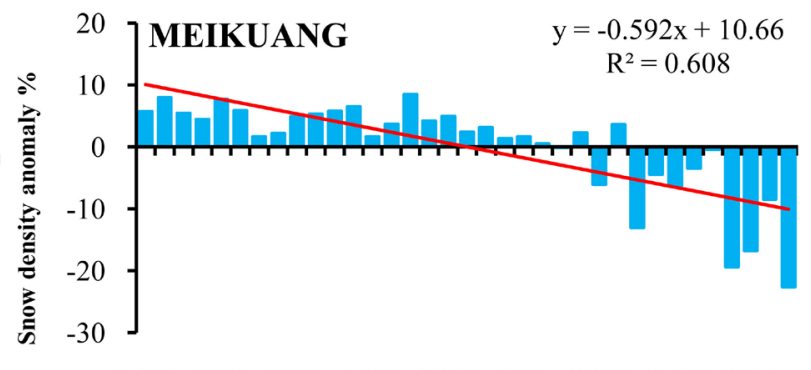

197919831987199119951999200320072011

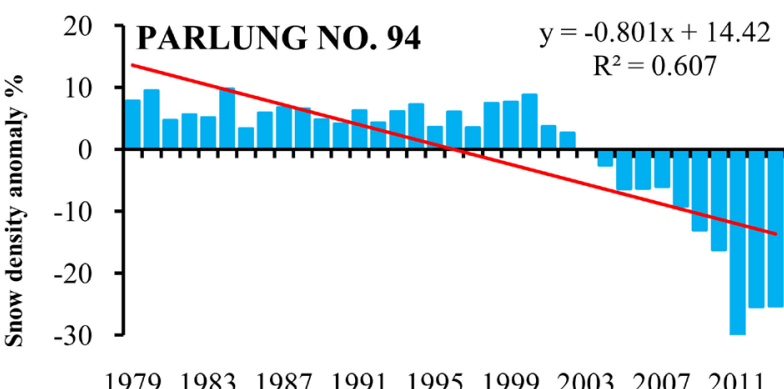

$\begin{array}{lllllllll}1979 & 1983 & 1987 & 1991 & 1995 & 1999 & 2003 & 2007 & 2011\end{array}$

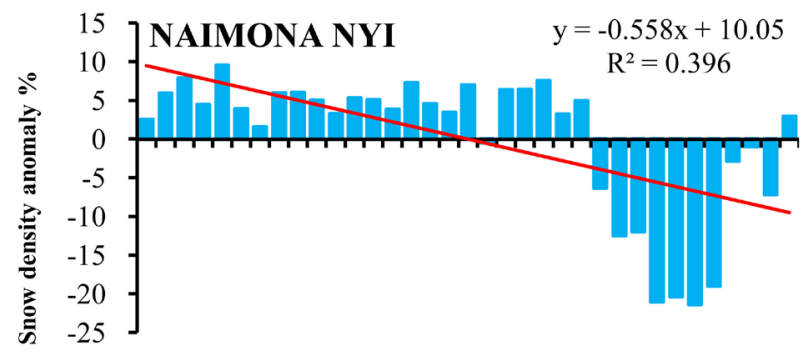

197919831987199119951999200320072011

Figure 5. The annual snow density anomaly\% of the nine stations during 1979-2013. 

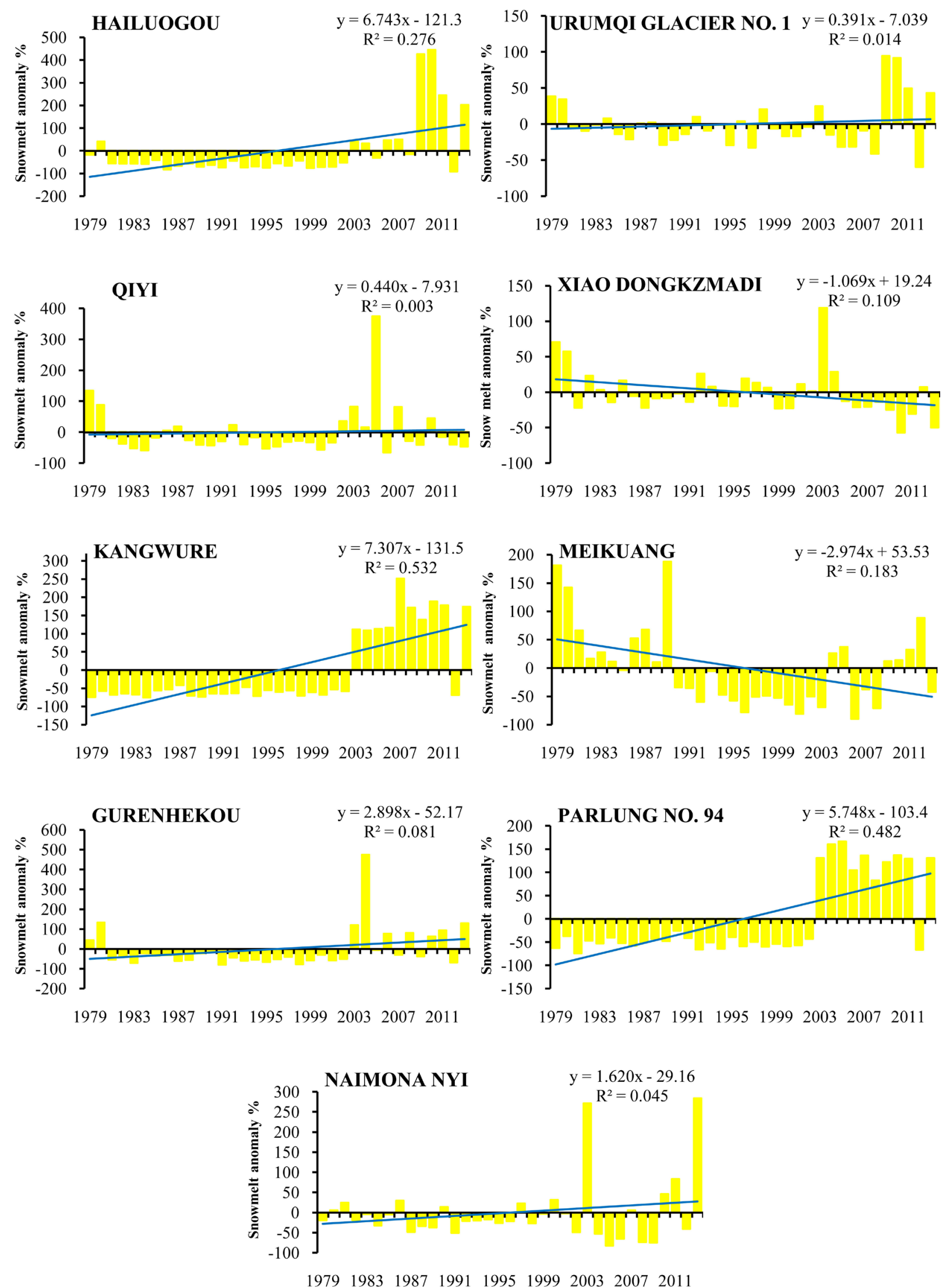

Figure 6. The annual snowmelt anomaly\% of the nine stations during 1979-2013. 


\subsection{The Snow Depth}

The decreasing rate of annual snow depth anomaly\% was $-31.71 / 10 \mathrm{a},-2.02 / 10 \mathrm{a}$, $-1.74 / 10 \mathrm{a},-17.56 / 10 \mathrm{a},-4.93 / 10 \mathrm{a},-4.93 / 10 \mathrm{a}$, respectively in URUMQI GLACIER NO. 1, QIYI, XIAO DONGKZMADI, KANGWURE, PARLUNG NO. 94 and NAIMONA NYI as shown in Figure 7. In Tianshan, the glaciers have responded differently according to their annual mass balances, lengths, areas, equilibrium line altitudes that are responses to increase in both temperature and precipitation. URUMQI GLACIER NO. 1 branches can indicate climate changes at the Urumqi River head region, especially the temperature variation [36]. During 1958-2007, the QIYI station showed a significant negative correlation exists between temperature with mass balance, area, length and thickness are respectively $-0.59,-0.65,-0.63$, and -0.65 [37].

\subsection{The Runoff}

As shown in Figure 8, a high increasing rate of annual runoff anomaly\% occurred in HAILUOGOU, URUMQI GLACIER NO. 1, QIYI, XIAO DONGKZMADI, KANGWURE, MEIKUANG and GURENHEKOU at the rates of 1/10a, 18.43/10a, 25.97/10a, 11.25/10a, 4.9/10a, 15.29/10a and 25.77/10a, respectively. The runoff has increased significantly since the $1980 \mathrm{~s}$, flowing out from the Tianshan Mountains. The glacial retreat has a major impact on water resources in arid regions [38]. There is a significant positive correlation existing between air temperature and river fluxes in both catchments, especially in the glacial catchment in the Urumqi River in the eastern Tianshan [39]. In Tianshan, as estimated by Min et al. [14], the increase of runoff occurred mainly in the ablation season (from May to October). Increased runoff is concentrated mainly in June, July, and August. Within this period, radiation is sufficient and increased precipitation on the glacier leads to melt, which leads to increased runoff in the watershed. The increase in air temperature and precipitation has a great influence on the seasonal distribution of runoff. Nam Co Lake in the Nyainqentanglha mountain glacier has increased from $1998.78 \pm 5.4$ to $2023.8 \pm$ $3.4 \mathrm{~km}^{2}$, the glacier-covered area has decreased from 832.34 to $821.0 \mathrm{~km}^{2}$ and the drainage basin area has decreased from $201.1 \pm 4.2$ to $196.1 \pm 2.3 \mathrm{~km}^{2}$. However, the most spectacular feature is the continual water level rise from 2003 to 2009 without an obvious associated increase in precipitation [34]. The glacial lakes in the central Himalaya expanded rapidly by $17.11 \%$ from 1990 to 2010 [40].

\section{Discussions}

As shown in Table 2, Hailuogou station showed there is a correlation coefficient between annual temperature with annual density negative relationship ( $\mathrm{CC}=$ $-0.398^{\star}$ ) and positive relationship between annual temperature with annual snowmelt $\left(\mathrm{CC}=0.608^{\star *}\right)$. The correlation coefficients of annual temperature with annual mass balance, snow density and snow depth at the URUMQI GLACIER NO. 1 station, respectively are significantly negative relationship (CC 

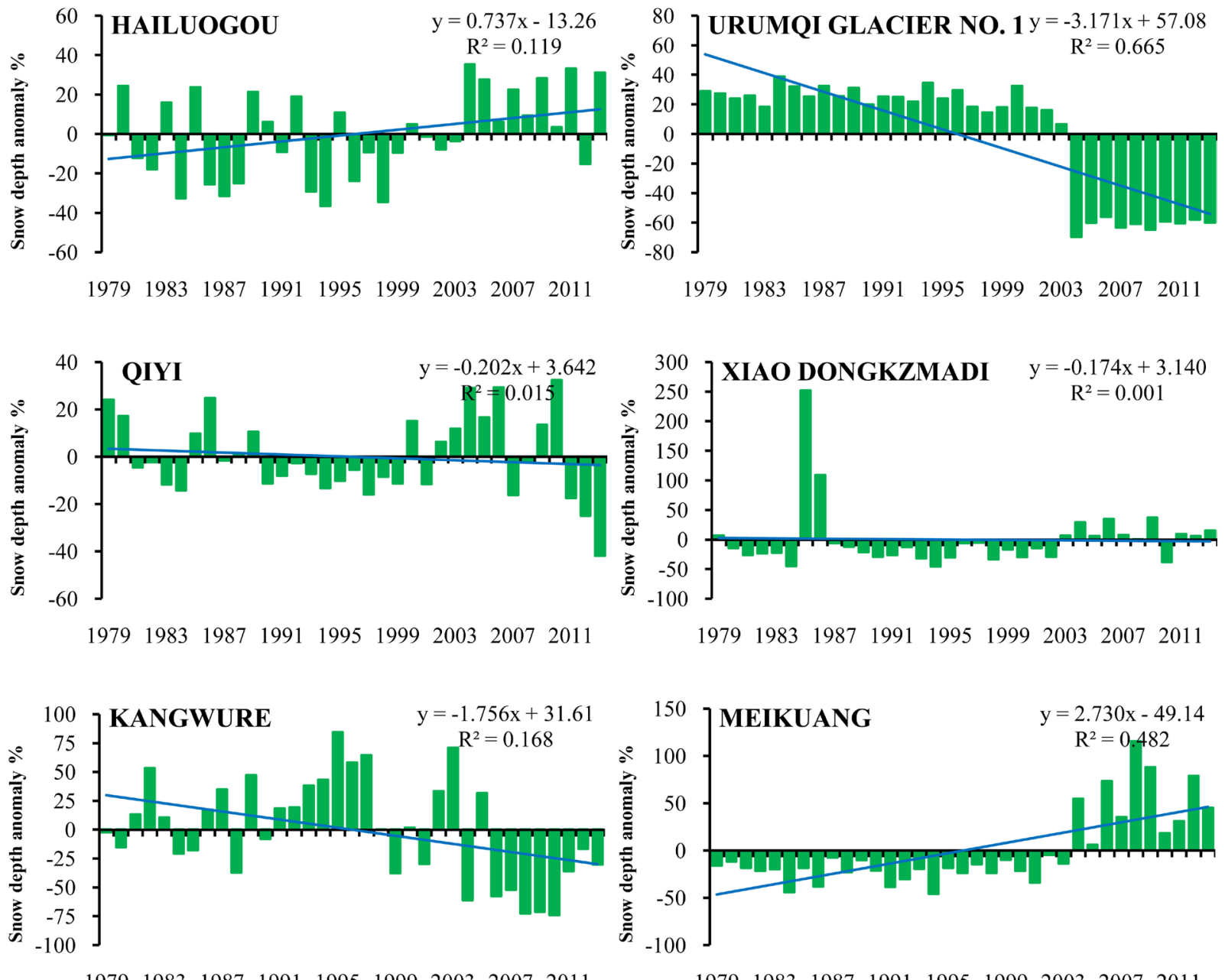

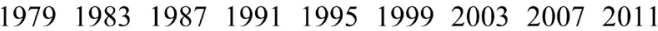

$\begin{array}{lllllllll}1979 & 1983 & 1987 & 1991 & 1995 & 1999 & 2003 & 2007 & 2011\end{array}$
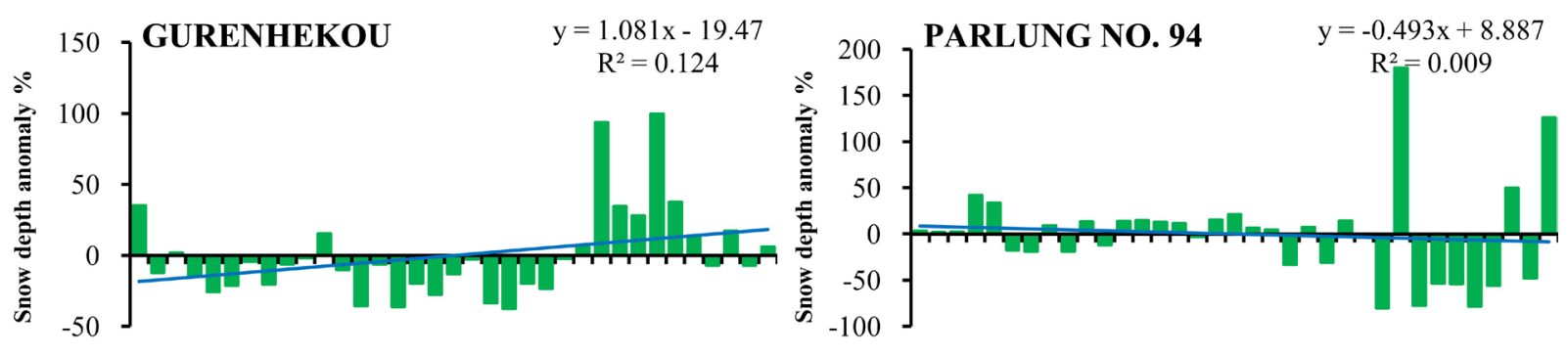

197919831987199119951999200320072011

197919831987199119951999200320072011

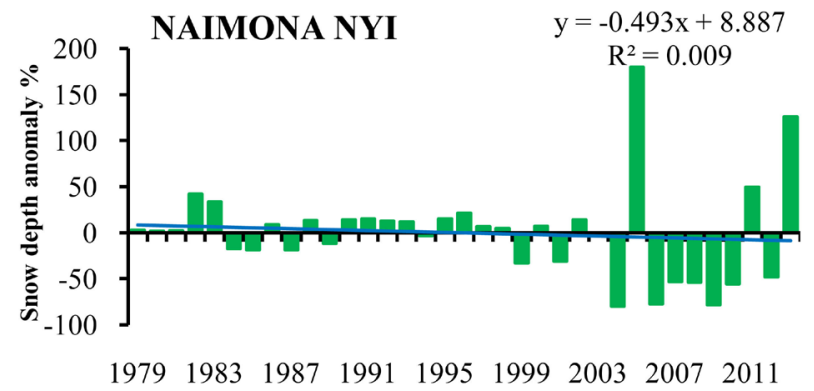

Figure 7. The annual snow depth anomaly\% of the nine stations during 1979-2013. 

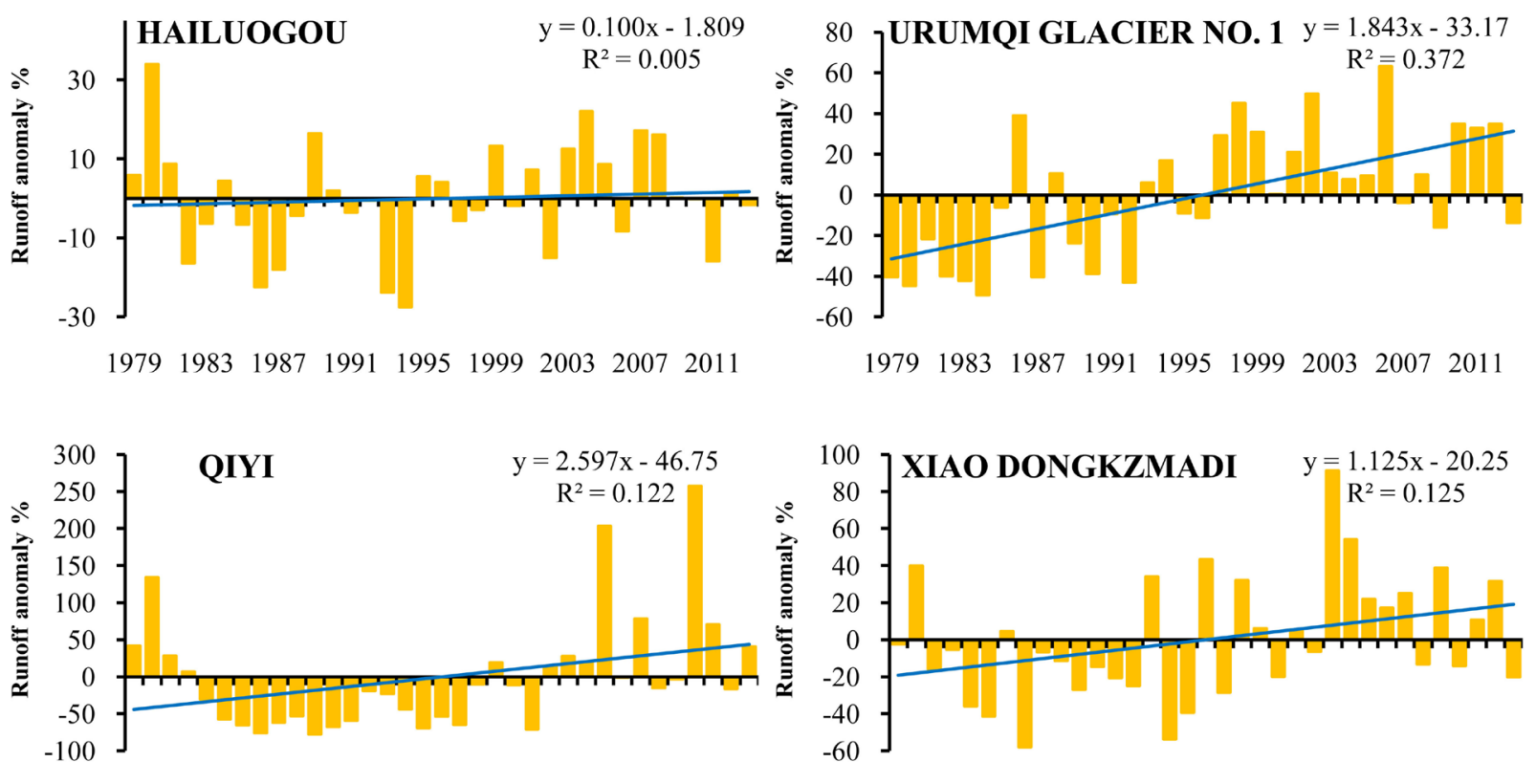

$\begin{array}{lllllllll}1979 & 1983 & 1987 & 1991 & 1995 & 1999 & 2003 & 2007 & 2011\end{array}$

197919831987199119951999200320072011
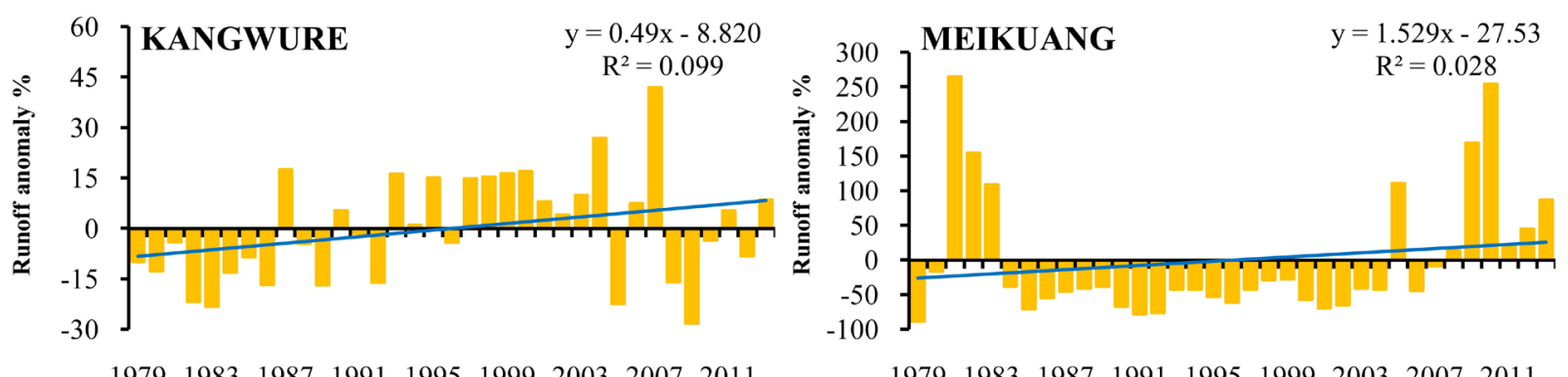

$\begin{array}{lllllllll}1979 & 1983 & 1987 & 1991 & 1995 & 1999 & 2003 & 2007 & 2011\end{array}$

$\begin{array}{lllllllll}1979 & 1983 & 1987 & 1991 & 1995 & 1999 & 2003 & 2007 & 2011\end{array}$

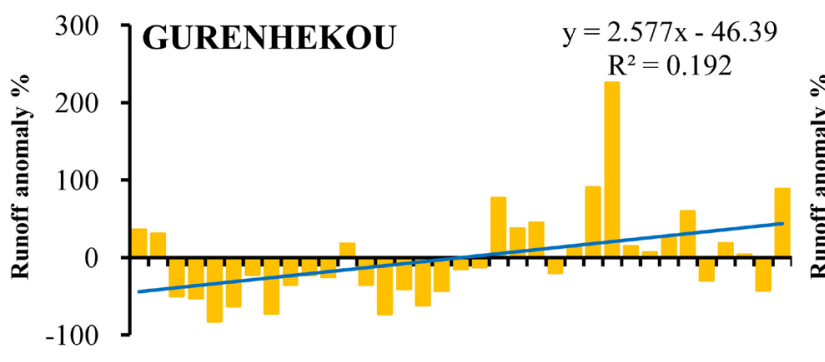

$\begin{array}{lllllllll}1979 & 1983 & 1987 & 1991 & 1995 & 1999 & 2003 & 2007 & 2011\end{array}$

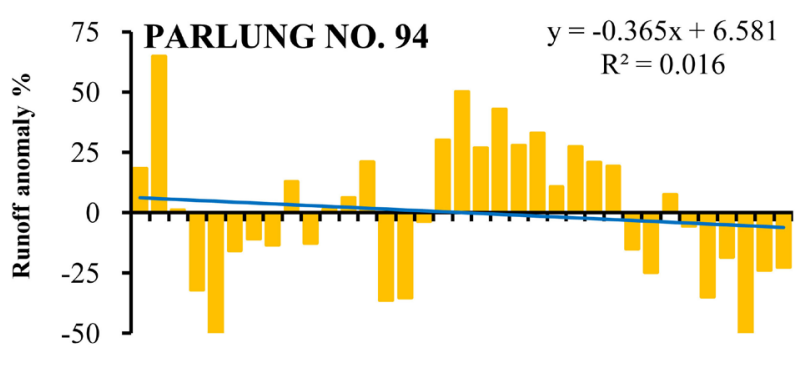

197919831987199119951999200320072011

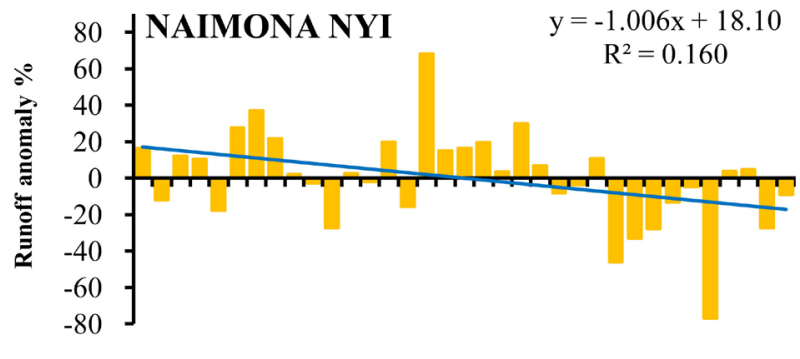

197919831987199119951999200320072011

Figure 8. The annual runoff anomaly\% of the nine stations during 1979-2013. 
Table 2. The correlation coefficient between temperature with snow density, snowmelt, snow depth and runoff in the nine stations during 1979-2013.

\begin{tabular}{|c|c|c|c|c|c|c|c|c|c|c|c|}
\hline & \multirow{2}{*}{ Station name } & \multicolumn{2}{|c|}{ Mass balance } & \multicolumn{2}{|c|}{ Snow density } & \multicolumn{2}{|c|}{ Snowmelt } & \multicolumn{2}{|c|}{ Snow depth } & \multicolumn{2}{|c|}{ Runoff } \\
\hline & & Sig. & $\mathrm{P}$ & Sig. & $\mathrm{P}$ & Sig. & $\mathrm{P}$ & Sig. & $\mathrm{P}$ & Sig. & $\mathrm{P}$ \\
\hline 1 & Hailuogou & -0.30 & 0.63 & $-0.398^{*}$ & 0.02 & $0.608^{* *}$ & 0.00 & 0.05 & 0.76 & -0.08 & 0.63 \\
\hline 2 & Urumqi Glacier No. 1 & $-0.589^{\star *}$ & 0.00 & $-0.512^{\star *}$ & 0.00 & 0.21 & 0.23 & $-0.630^{\star \star}$ & 0.00 & $0.556^{\star *}$ & 0.00 \\
\hline 3 & Qiyi & $-0.665^{\star}$ & 0.02 & $-0.501^{\star *}$ & 0.00 & 0.10 & 0.55 & -0.05 & 0.80 & 0.33 & 0.05 \\
\hline 4 & Xiao Dongkzmadi & $-0.657^{\star \star}$ & 0.00 & -0.21 & 0.22 & -0.30 & 0.08 & -0.29 & 0.09 & $0.423^{*}$ & 0.01 \\
\hline 5 & Kangwure & -0.47 & 0.53 & $-0.486^{\star *}$ & 0.00 & $0.598^{* *}$ & 0.00 & $-0.642^{\star *}$ & 0.00 & 0.32 & 0.06 \\
\hline 6 & Meikuang & -0.13 & 0.68 & $-0.673^{\star *}$ & 0.00 & -0.275 & 0.11 & 0.23 & 0.00 & 0.25 & 0.15 \\
\hline 7 & Gurenhekou & $-0.987^{\star \star}$ & 0.00 & $-0.454^{\star \star}$ & 0.01 & 0.09 & 0.59 & 0.27 & 0.11 & 0.30 & 0.08 \\
\hline 9 & Naimona Nyi & 0.77 & 0.12 & $-0.546^{\star *}$ & 0.00 & 0.03 & 0.84 & $-0.387^{\star}$ & 0.02 & -0.26 & 0.13 \\
\hline
\end{tabular}

Note: ${ }^{\star}$ means at a significance level of $0.05 ;{ }^{* *}$ means at a significance level of 0.01 .

$=-0.589^{\star *},-0.512^{\star *}$ and $\left.-0.630^{\star *}\right)$, also there is a significantly positive correlation of annual temperature with Runoff $\left(\mathrm{CC}=0.556^{* *}\right)$. The QIYI station showed a significantly negative correlation of annual temperature with annual balance and annual snow density $\left(\mathrm{CC}=-0.665^{\star}\right.$ and $-0.501^{\star \star}$, respectively). The XIAO DONGKZMADI station showed a significant negative correlation between annual temperature with annual balance $\left(\mathrm{CC}=-0.657^{\star *}\right)$, also there is a significantly positive correlation of annual temperature with Runoff (CC $0.423^{*}$ ). The KANGWURE station showed a significant negative correlation between annual temperature with annual snow density and snow depth $\left(\mathrm{CC}=-0.486^{\star *}\right.$ and $-0.642^{* *}$, respectively), while a positive correlation of annual temperature with annual snowmelt $\left(\mathrm{CC}=0.598^{\star *}\right)$. The MEIKUANG station showed a significant negative correlation of annual temperature with annual snow density $\left(\mathrm{CC}=-0.673^{\star *}\right)$. The GURENHEKOU station showed a significant negative correlation of annual temperature with annual balance and annual snow density (CC $=-0.987^{\star \star}$ and $-0.454^{\star *}$, respectively). The PARLUNG NO. 94 station showed a significant negative correlation between annual temperature with annual snow density $\left(\mathrm{CC}=-0.468^{\star *}\right)$, while there is a significant positive correlation between annual temperature with annual snowmelt $\left(\mathrm{CC}=0.568^{\star *}\right)$. The NAIMONA NYI station showed a significant negative correlation of annual temperature with annual snow density and annual snow depth $\left(\mathrm{CC}=-0.546^{\star *}\right.$ and $-0.387^{\star}$, respectively).

The average temperature of the nine stations during 1979-2013 showed a highly increasing trend at the rate of $0.46^{\circ} \mathrm{C} / 10 \mathrm{a}$, which has resulted in an increasing trend of annual snowmelt and runoff anomaly at the rate of $24.82 \% / 10 \mathrm{a}$ and $9.87 \% / 10 \mathrm{a}$, respectively. On the other hand, there was a declining trend in annual snow density and snow depth anomaly at the rate of $-5.32 \% / 10 \mathrm{a}$ and $-1.93 \% / 10 a$, respectively (Figure 9). [7] reported that the ice volume in Urumqi 
Glacier No. 1 was decreased during 1981-2006, which caused glacier thinning. Thus, these changes were responses to the regional climatic warming, which showed a dramatic increase of $0.6^{\circ} \mathrm{C} / 10 \mathrm{a}$ during the 25 years (1979-2013). In fact, under the global warming, glaciers are experiencing the heavy amount of glacier ablation around the world, which caused the sea-level rise and mountain [41]. The results in Table 3 showed that the correlation coefficient of mean

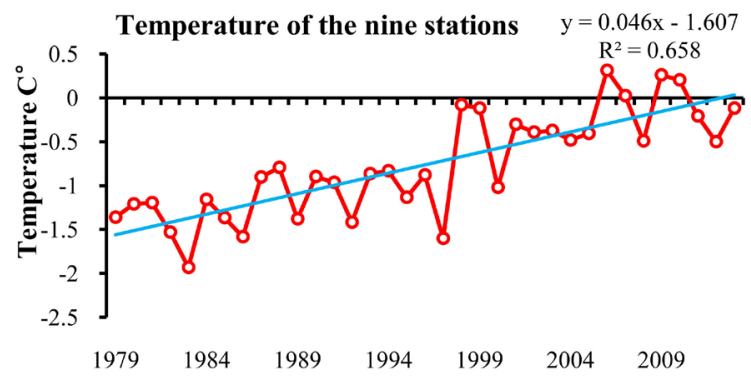

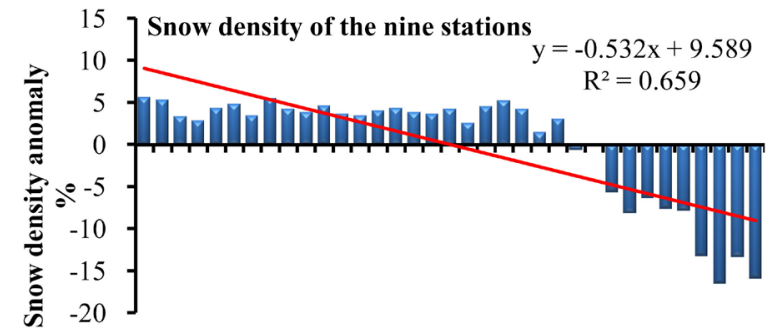

197919831987199119951999200320072011

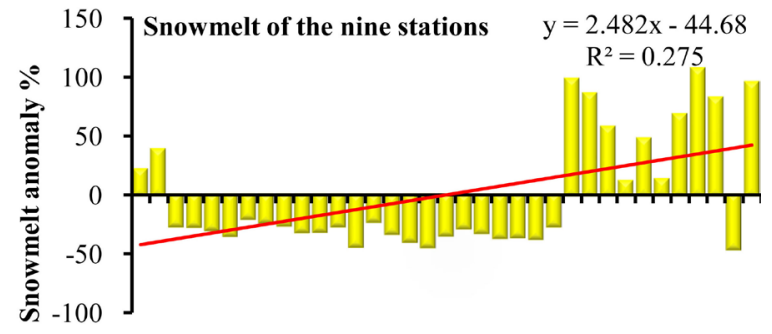

197919831987199119951999200320072011
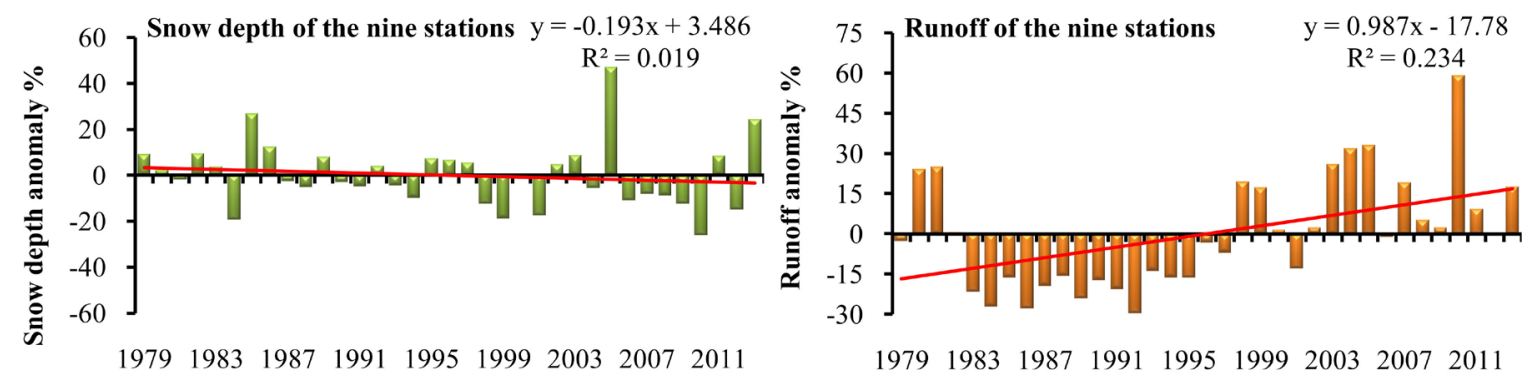

Figure 9. Cumulative changes of mean temperature, snow density, snowmelt, snow depth and runoff during 1979-201.

Table 3. The correlation coefficient of the mean of the nine stations, firstly between temperature and snow density, snowmelt, snow depth and runoff. Secondly, between snow density and snowmelt, snow depth and runoff, thirdly between snowmelt and snow depth and runoff, finally snow depth with runoff, the correlation coefficient during 1979-2013.

\begin{tabular}{cccccccccc}
\hline & \multicolumn{2}{c}{ Snow density } & \multicolumn{2}{c}{ Snowmelt } & \multicolumn{2}{c}{ Snow depth } & \multicolumn{2}{c}{ Runoff } \\
\cline { 2 - 9 } & Sig. value & P value & Sig. value & P value & Sig. value & P value & Sig. value & P value \\
\hline Temperature & $-0.661^{* *}$ & 0.00 & $0.532^{* *}$ & 0.00 & $-0.342^{*}$ & 0.04 & $0.586^{* *}$ & 0.00 \\
Snow density & & & $-0.662^{* *}$ & 0.00 & 0.02 & 0.92 & $-0.491^{* *}$ & 0.00 \\
Snowmelt & & & & & 0.17 & 0.34 & $0.712^{* *}$ & 0.00 \\
Snow depth & & & & & & & -0.03 & 0.86 \\
\hline
\end{tabular}

Note: ${ }^{*}$ means at significance level of $0.05 ;{ }^{* *}$ means at significance level of 0.01 . 
temperature of the nine stations during 1979-2013 has a highly significant negative relationship with snow density $\left(\mathrm{CC}=-0.661^{\star *}\right.$ at 0.01 level $)$. There is a high positive relationship between temperature with snowmelt $\left(C C=0.532^{\star *}\right.$ at 0.01 level), in addition, a positive relationship between temperature and runoff has a correlation coefficient of $0.586^{\star \star}$ at 0.01 level. In addition, representative relationships between all parameters have clearly shown in Figure 10 in horizontal
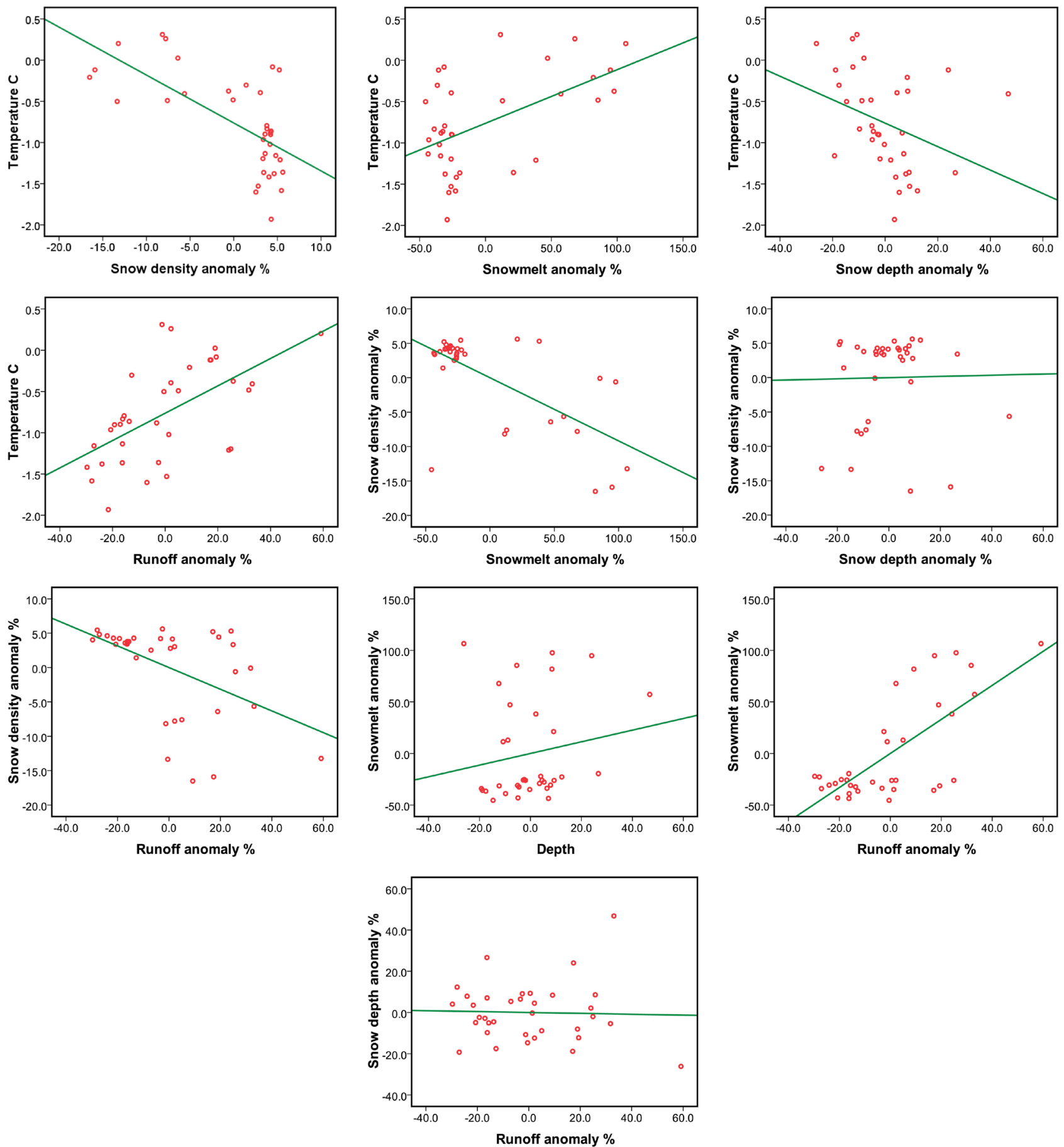

Figure 10. The relationships between the parameters of mean the nine stations that have shown in horizontal and vertical axis during 1979-2013. 
and vertical axis during 1979-2013.

\section{Conclusions}

The present study confirms continuous glacier mass loss and accelerated glacier area shrinkage during the period 1979-2013 on nine glacier stations in China. Accordingly, this research provided a brief overview of major glacier balance change, snow density, snowmelt and runoff. Moreover, this study provides baseline knowledge to analyze data and research on a climate change adaptation perspective to reduce the negative impacts on melt and runoff, which have serious implications for human societies due to depending on fresh water from cryospheric sources.

The survey results showed that the significant increase in temperature during the past half century has a high relationship with melting glacier in China. In fact, study area showed a retreat of snow density and snow depth, on the other hand, increase in snowmelt and runoff. Both changes have highly significant correlations with temperature increase. In suggestions, we call to better preparedness and strategies to create good plans that can adapt with climatic and cryospheric variables. Thus, an adaptation to negative impacts of climate change on glaciers is foremost a challenge that has to be tackled at the local or regional scale and within the societal context of the target region.

\section{Acknowledgements}

The present research was supported by the National Natural Science Foundation of China (Grant number 41471058 and 41641003), the NSFC project (Grant number 91425303) and the SKLCS funding (SKLCS-ZZ-2018).

\section{References}

[1] ACIA (2005) Arctic Climate Impact Assessment. Cambridge Univ. Press, New York, $1024 \mathrm{p}$.

[2] Bolch, T., Kulkarni, A., Kääb, A., Huggel, C., Paul, F., Cogley, J.G., Frey, H., Kargel, J.S., Fujita, K., Scheel, M., Bajracharya, S. and Stoffel, M. (2012) The State and Fate of Himalayan Glaciers. Science, 336, 310-315. https://doi.org/10.1126/science.1215828

[3] Marzeion, B., Cogley, J.G., Richter, K. and Parkes, D. (2014) Attribution of Global Glacier Mass Loss to Anthropogenic and Natural Causes. Science, 345, 919-921. https://doi.org/10.1126/science. 1254702

[4] Immerzeel, W. (2008) Historical Trends and Future Predictions of Climate Variability in the Brahmaputra Basin. Int J Climatol, 28, 243-254. https://doi.org/10.1002/joc.1528

[5] Lang, C., Fettweis, X. and Erpicum, M. (2015) Future Climate and Surface Mass Balance of Svalbard Glaciers in an RCP8.5 Climate Scenario: A Study with the Regional Climate Model MAR Forced by MIROC5. The Cryosphere, 9, 945-956. https://doi.org/10.5194/tc-9-945-2015

[6] Wang, P.Y., Li, Z.Q., Wang, W.B., Li, H.L., Zhou, P. and Jin, S. (2013) Changes of Six Selected Glaciers in the Tomor Region, Tian Shan, Central Asia, over the Past 50 
Years, Using High-Resolution Remote Sensing Images and Field Surveying. Quaternary International, 311, 123-131. https://doi.org/10.1016/j.quaint.2013.04.031

[7] Wang, P.Y., Li, Z.Q., Jin, S., Zhou, P., Yao, H.B. and Wang, W.B. (2014) Ice Thickness, Volume and Subglacial Topography of Urumqi Glacier No. 1, Tianshan Mountains, Central Asia, by Ground Penetrating Radar Survey. J. Earth Syst. Sci, 123, 581-591. https://link.springer.com/article/10.1007\%2Fs12040-014-0421-4

[8] Ravazzani, G., Barbero, S., Salandin, A., Senatore, A. and Mancini, M. (2015) An Integrated Hydrological Model for Assessing Climate Change Impacts on Water Resources of the Upper Po River Basin. Water Resour.Manag, 29, 1193-1215. https://doi.org/10.1007/s11269-014-0868-8

[9] Vergara, W., Deeb, A., Valencia, A., Bradley, R., Francou, B., Zarzar, A., Grünwaldt, A. and Haeussling, S. (2007) Economic Impact of Rapid Glacier Retreat in the Andes. Eos, 88, 261-269. https://doi.org/10.1029/2007EO250001

[10] Beniston, M., Stoffel, M. and Hill, M. (2011) Impacts of Climatic Change on Water and Natural Hazards in the Alps: Can Current Water Governance Cope with Future Challenges? Examples from the European "ACQWA" Project. Environ. Sci. Pol., 14, 734-743. https://doi.org/10.1016/j.scitotenv.2013.11.122

[11] Paterson, W.S.B. (1994) The Physics of Glaciers. 3rd Edition, Pergamon, Oxford, $480 \mathrm{p}$.

[12] Sorg, A., Huss, M., Rohrer, M. and Stoffel, M. (2014) The Days of Plenty Might Soon Be over in Glacierized Central Asian Catchments. Environ. Res. Lett, 9, Article ID: 104018. https://doi.org/10.1088/1748-9326/9/10/104018

[13] Kamb, B., Raymond, C.F., Harrison, W.D., Engelhardt, H., Echelmeyer, K.A., Humphrey, N., Brugman, M.M. and Pfeffer, T. (1985) Glacier Surge Mechanism: 1982-1983 Surge of Variegated Glacier, Alaska. Sci. New Ser, 227, 469-479. https://doi.org/10.1126/science.227.4686.469

[14] Min, X., Haidong, H. and Shi, C.K. (2017) Modeling Glacier Mass Balance and Runoff in the Koxkar River Basin on the South Slope of the Tianshan Mountains, China, from 1959 to 2009. MDPI Water, 9, 2-19.

[15] Häusler, H., Ng, F., Kopecny, A. and Leber, D. (2016) Remote-Sensing-Based Analysis of the 1996 Surge of Northern Inylchek Glacier, Central Tien Shan, Kyrgyzstan. Geomorphology, 273, 292-307. https://doi.org/10.1016/j.geomorph.2016.08.021

[16] Wu, Y.W., Wang, N.L., He, J.Q. and Jiang, X. (2015) Estimating Mountain Glacier Surface Temperatures from Landsat-ETM + Thermal Infrared Data: A Case Study of Qiyi Glacier, China. Remote Sensing of Environment, 163, 286-295. https://doi.org/10.1016/j.rse.2015.03.026

[17] Shi, P., Sun, S., Wang, M., Li, N., Wang, J., Jin, Y., Gu,, X. and Yin, W. (2014) Climate Change Regionalization in China (1961-2010). Sci. China Earth Sci, 57, 2676-2689. https://doi.org/10.1007/s11430-014-4889-1

[18] IPCC (2013) Working Group I Contribution to the Fifth Assessment Report of the Intergovernmental Panel on Climate Change The Physical Science Basis, Summary for Policymakers, Climate Change 2013.

https://www.ipcc.ch/pdf/assessment-report/ar5/wg1/WGIAR5_SPM_brochure_en.p $\underline{\mathrm{df}}$

[19] Bhogendra, M., Mukand, S.B. and Nitin, K.T. (2014) Analysis of Climatic Variability and Snow Cover in the Kaligandaki River Basin, Himalaya, Nepal. Theor Appl Climatol, 116, 681-694. https://doi.org/10.1007/s00704-013-0966-1

[20] Petrakov, D., Shpuntova, A., Aleinikov, A., Kääb, A., Kutuzov, S., Lavrentiev, I., 
Stoffel, M., Tutubalina, O. and Usubaliev, R. (2016) Accelerated Glacier Shrinkage in the Ak-Shyirak Massif, Inner Tien Shan, during 2003-2013. Science of the Total Environment, 562, 364-378. https://doi.org/10.1016/j.scitotenv.2016.03.162

[21] Zemp, M., Frey, H., Gartner-Roer, I., Nussbaumer, S.U., Hoelzle, M., Paul, F., Haeberli, W., Denzinger, F., Ahlstrom, A.P., Anderson, B., Bajracharya, S., Baroni, C., Braun, L.N., Caceres, B.E., Casassa, G., Cobos, G., Davila, L.R., Delgado, G.H., Demuth, M.N., Espizua, L., Fischer, A., Fujita, K., Gadek, B., Ghazanfar, A., Hagen, J.O., Holmlund, P., Karimi, N., Li, Z., Pelto, M., Pitte, P., Popovnin, V.V., Portocarrero, C.A., Prinz, R., Sangewar, C.V., Severskiy, I., Sigurðsson, O., Soruco, A., Usubaliev, R. and Vincent, C. (2015) Historically Unprecedented Global Glacier Decline in the Early 21st Century. J. Glaciol, 61, 745-762. https://doi.org/10.3189/2015JoG15J017

[22] Pratap, B., Dobhal, D.P., Bhambri, R., Mehta, M. and Tewari, V.C. (2016) Four Decades of Glacier Mass Balance Observations in the Indian Himalaya. Reg. Environ. Change, 16, 643-658. https://doi.org/10.1007/s10113-015-0791-4

[23] Su, Z. and Shi, Y. (2002) Response of Monsoonal Temperate Glaciers to Global Warming Since the Little Ice Age. Quaternary International, 97-98, 123-131. https://doi.org/10.1016/S1040-6182(02)00057-5

[24] Che, Y.J., Zhang, M.J., Li, Z.Q., Li, H.L., Wang, S.J., Sun, M.P. and Zh, S.P. (2017) Glacier Mass-Balance and Length Variation Observed in China during the Periods 1959-2015 and 1930-2014. Quaternary International, 445, 68-84. https://doi.org/10.1016/j.quaint.2017.07.003

[25] Dobhal, D., Gergan, J.T. and Thayyen, R. (2004) Recession and Morphogeometrical Changes of Dokriani Glacier (1962-1995), Garhwal Himalaya, India. Curr Sci, 86, 692-696.

[26] Bolch, T., Buchroithner, M., Pieczonka, T. and Kunert, A. (2008) Planimetric and Volumetric Glacier Changes in the Khumbu Himal, Nepal, Since 1962 Using Corona, Landsat TM and ASTER Data. J Glaciol, 54, 592-600. https://doi.org/10.3189/002214308786570782

[27] Adam, J.C., Hamlet, A.F. and Lettenmaier, D.P. (2009) Implications of Global Climate Change for Snowmelt Hydrology in the Twenty-First Century. Hydrol Process, 23, 962-972. https://doi.org/10.1002/hyp.7201

[28] Wang, P.Y., Li, Z.Q., Wang, W.B., Li, H.L., Wu, L.H., Huai, B.J., Zhou, P., Jin, S. and Wang, L. (2016) Comparison of Changes in Glacier Area and Thickness on the Northern and Southern Slopes of Mt. Bogda, Eastern Tianshan Mountains. Journal of Applied Geophysics, 132, 164-173. https://doi.org/10.1016/j.jappgeo.2016.07.009

[29] Ma, L.L., Tian, L.D., Pu, J.C. and Wang, P.L. (2010) Recent Area and Ice Volume Change of Kangwure Glacier in the Middle of Himalayas. Chinese Science Bulletin, 55, 2088-2096.

[30] Shangguan, D.H., Liu, S.Y. and Ding, L.F. (2008) Variation of Glaciers in the Western Nyainqêntanglha Range of Tibetan Plateau during 1970-2000. J Glaciol Geocryol, 30, 204-210. (In Chinese)

[31] Yu, W.S., Yao, T.D., Kang, S.H., Pu, J.C., Yang, W., Gao, T.G., Zhao, H.B., Zhou, H., Li, S.H., Wang, W.C. and Ma, L.L. (2013) Different Region Climate Regimes and Topography Affect the Changes in Area and Mass Balance of Glaciers on the North and South Slopes of the Same Glacierized Massif (the West Nyainqentanglha Range, Tibetan Plateau). Journal of Hydrology, 495, 64-73. https://doi.org/10.1016/j.jhydrol.2013.04.034

[32] Liu, Y.S., Qin, X., Zhang, T., Zhang, M.J. and Du, W.T. (2013) The Change of 
Ningchan River Glacier No. 3 at Lenglongling, East Qilian Mountain, China. Sciences in Cold and Arid Regions, 5, 0709-0714. https://doi.org/10.3724/SP.J.1226.2013.00709

[33] Xu, X.K. and Glasser, N.F. (2015) Glacier Sensitivity to Equilibrium Line Altitude and Reconstruction for the Last Glacial Cycle: Glacier Modeling in the Payuwang Valley, Western Nyaiqentanggulha Shan, Tibetan Plateau. Palaeogeography, Palaeoclimatology, Palaeoecology, 440, 614-620. https://doi.org/10.1016/j.palaeo.2015.09.025

[34] Hongbo, W.U., Ninglian, W., Xi, J. and Zhongming, G. (2014) Variations in Water Level and Glacier Mass Balance in Nam Co Lake, Nyainqentanglha Range, Tibetan Plateau, Based on ICESat Data for 2003-09. Annals of Glaciology, 55, 239-247. https://doi.org/10.3189/2014AoG66A100

[35] Kääb, A., Treichler, D., Nuth, C. and Berthier, E. (2015) Brief Communication: Contending Estimates of 2003-2008 Glacier Mass Balance over the $\mathrm{Pa}$ mir-Karakoram-Himalaya. Cryosphere, 9, 557-564. https://doi.org/10.5194/tc-9-557-2015

[36] Xu, X.K., Pan, B., Hu, E., Li, Y.J. and Liang, Y.H. (2011) Responses of Two Branches of Glacier No. 1 to Climate Change from 1993 to 2005, Tianshan, China. Quaternary International, 236, 143-150. https://doi.org/10.1016/j.quaint.2010.06.013

[37] Jing, Z.F., Liu, L., Zhou, Z.M. and Deng, Y.F. (2012) Analysis on Factors of Glacier Velocity: A Case Study of the Qiyi Glacier, Qilian Mountains. Sciences in Cold and Arid Regions, 4, 0275-0280. https://doi.org/10.3724/SP.J.1226.2012.00275

[38] Li, K., Li, Z., Gao, W. and Wang, L. (2011) Recent East Tianshan Glacier Retreat and Its Impact on Water Resources. Chin. Sci. Bull, 56, 27082716.

[39] Li, Z.Q., Gao, W.H., Zhang, M.J. and Gao, W.Y. (2012) Variations in Suspended and Dissolved Matter Fluxes from Glacial and Non-Glacial Catchments during a Melt Season at Urumqi River, Eastern Tianshan, Central Asia. Catena, 95, 42-49. https://doi.org/10.1016/j.catena.2012.03.00

[40] Nie, Y., Liu, Q. and Liu, S. (2013) Glacial Lake Expansion in the Central Himalayas by Landsat Images, 1990-2010. PLoS ONE, 8, e83973. https://doi.org/10.1371/journal.pone.0083973

[41] Jevrejeva, S., Moore, J.C. and Grinsted, A. (2008) Relative Importance of Mass and Volume Changes to Global Sea Level Rise. Journal of Geophysical Research, 113, D08105. https://doi.org/10.1029/2007JD009208 